\title{
Rilevamento a distanza: una metonimia per sperimentazioni tra didattica e ricerca
}

\author{
Caterina Palestini \\ Alessandro Basso
}

\begin{abstract}
Indagare l'astratto per il concreto nel retorico dualismo tra causa ed effetto, riferisce la sperimentazione condotta per la didattica a distanza in cui, non essendo possibile effettuare in presenza le consuete operazioni di rilevamento da svolgere con gli allievi, si è definita una metodologia operativa incentrata su esperienze di acquisizione dati tratti da contenuti informativi impiegando simulazioni virtuali. L'esperienza pone le basi su precedenti ricerche e sperimentazioni scientifiche che hanno messo a confronto acquisizioni da drone con tour virtuali che catturano le immagini dalla piattaforma divulgativa di Google Earth Pro. Il procedimento lowcost consente di ottenere rapidamente un modello di studio da impiegare come base per operazioni di rilevamento tramite rimodellazione, per la creazione di rappresentazioni derivanti da acquisizioni online.

Come premessa metodologia saranno illustrate e messe a confronto le applicazioni condotte in due ambiti conoscitivi a scala architettonica e territoriale, fornendo risultati e criticità conseguiti attraverso tali sistemi lowcost, per poi passare a descrivere i lavori ottenuti nel modello didattico messo in atto nella fase emergenziale della pandemia che ci ha costretto ad abbandonare repentinamente le consuete fasi operative del rilevamento per proiettarci nella formazione a distanza, non semplice per le specificità dell'ambito disciplinare. In sintesi, il contributo propone riflessioni operative da cui trarre spunto per esplorare le opportunità offerte dalla tecnologia, le potenzialità analitiche e rappresentative dei linguaggi digitali nel campo dei rilevamenti a distanza.
\end{abstract}

Parole chiave

rilevamento, metodologie lowcost, didattica a distanza, linguaggi digitali, fotomodellazione.

Rilevamenti a distanza da drone virtuale, fasi di acquisizione ed

elaborazione dati relativi allo studio del ponte Bac de Roda a Barcellona.

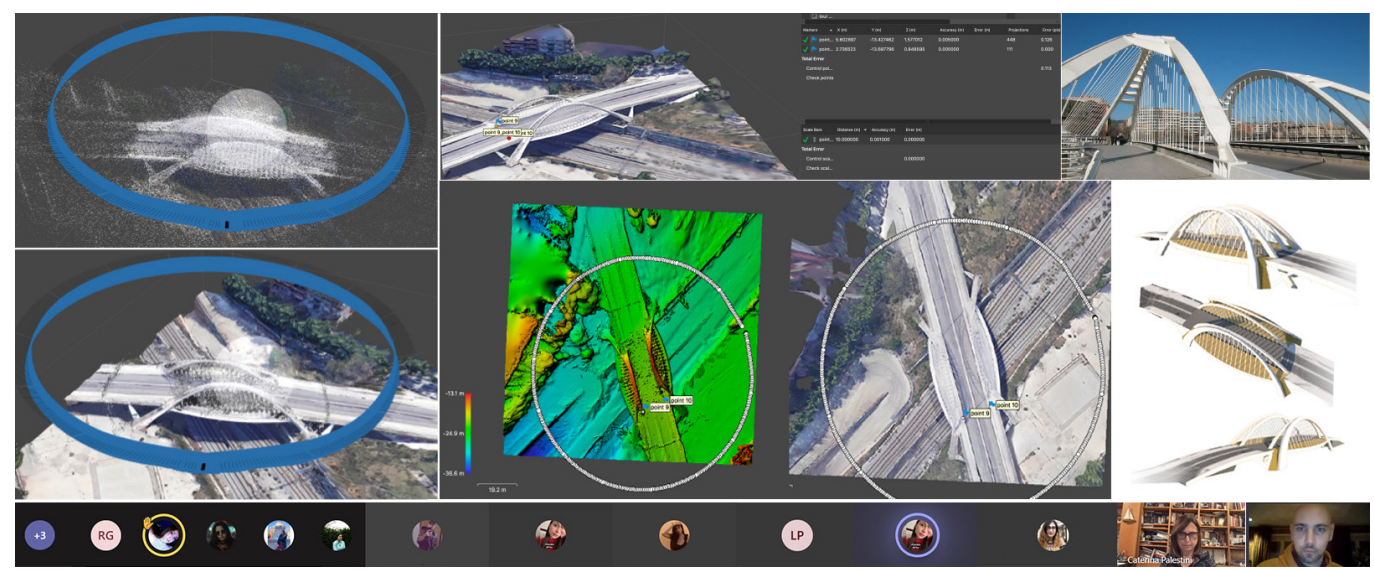




\section{Introduzione}

II contributo espone una metodologia operativa che adotta una modalità di acquisizione dati alternativa, mediante la quale vengono effettuate operazioni di fotomodellazione catturate su modelli $3 \mathrm{~d}$ elaborati dalla piattaforma divulgativa di Google Earth Pro. II procedimento lowcost consente di ottenere velocemente un primo modello di studio semi dettagliato da impiegare come base per operazioni di rimodellazione manuale e ritopologica, per la creazione di modelli territoriali 3d, per rendering o per la definizione di ambientazioni georeferenziate in cui si inseriscono i rilevamenti.

Google Earth, nato come strumento on line di supporto a una web directory basata su un'impostazione divulgativa, diviene in breve tempo uno strumento di indagine geografica con ambizioni GIS, tanto da essere utilizzato da aziende ed enti che impiegano tali dati all'interno dei loro progetti. L'approccio contemporaneo connesso alle dinamiche del web 2.0 guarda alla creazione dei contenuti informativi, di natura spaziale e non a diretta gestione dell'utente, di conseguenza, la maggior parte dei player tecnologici in ambito GIS (Autodesk, Bentley Systems, Intergraph, ESRI, Bing 3d ecc.) finiscono per ricalcare l'interfaccia di navigazione identificativa di Google Earth e Maps con il suo celebre globo tridimensionale e il comodo sistema di zoom satellitare. Inoltre, da qualche anno Google esegue un restyling delle sue dinamiche di esplorazione interattiva implementando interessanti aggiornamenti grafici che rendono ancora più utile la consultazione della app. Tra questi upgrade spicca l'utilizzo della fotogrammetria ad alto dettaglio, sfruttando aerei speciali, muniti di 5 camere con obiettivi grandangolari disposti sui quattro punti cardinali e in posizione perpendicolare al piano del terreno, la scansione fotogrammetrica 3d esegue l'acquisizione dei dati attraverso determinati percorsi di ripresa con andamento a zig-zag. Analogamente alle procedure impiegate per i rilievi aereo fotogrammetrici, eseguiti con camera metrica, vengono effettuati scatti con sequenze regolari funzionali ad ottenere una sovrapposizione di circa l'80\% gli uni con gli altri. I dati fotografici vengono poi ottimizzati e foto ritoccati dallo staff di Google, utilizzando in parte procedure grafiche automatiche, in modo da normalizzare l'aspetto cromatico, il disturbo digitale e gli eventuali artefatti che tendono ad omogeneizzare i dati fotografici. Queste procedure permettono di ridurre eventuali errori di deformazioni delle mesh nelle successive fasi di auto modellazione. II modello navigabile in real time restituisce dettagliatamente in $3 \mathrm{~d}$ estese porzioni di territorio fornendo una importante risorsa dati utilizzabile per molteplici usi.

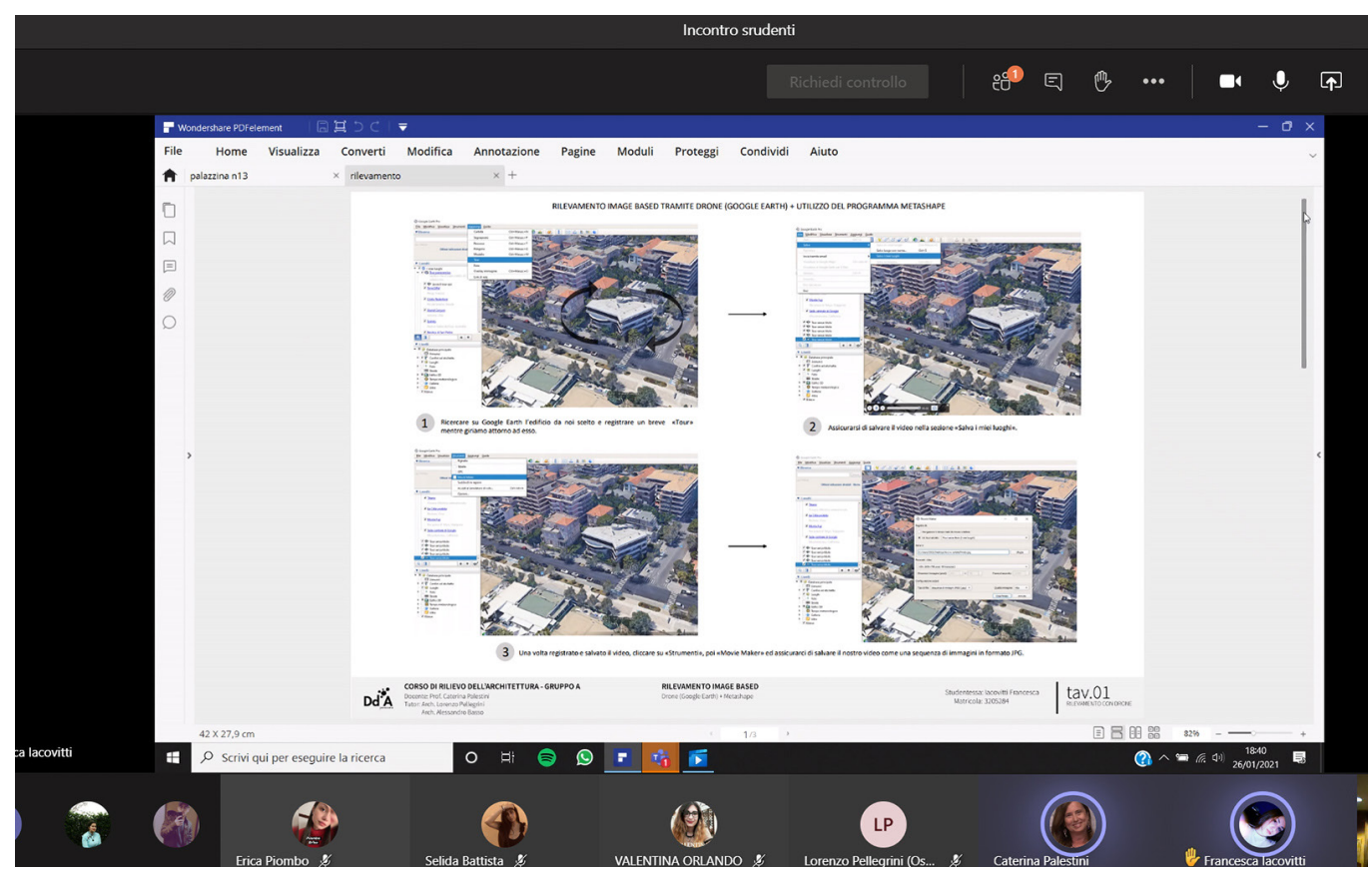


Nei mesi in cui si è sviluppata la pandemia è nata l'idea di utilizzare tali strumenti impiegando una metodologia sperimentale alternativa che ha permesso agli studenti di realizzare un rilevamento fotogrammetrico 3d senza ricorrere all'uso di droni o di strumentazioni Lidar per il rilevamento aereo, bypassando la fondamentale e necessaria fase di acquisizione dati in loco. Gli allievi sono stati così indirizzati verso l'applicazione della metodologia effettuabile in remoto, perseguendo l'obiettivo di considerare come oggetto di studio partizioni di territorio tridimensionale da cui ottenere risultati visivi immediati. II sistema ha consentito inoltre una veloce acquisizione di dati metrici finalizzati a una restituzione in scala che ha fornito soluzioni accettabili considerato il mancato utilizzo di specifiche strumentazioni. La procedura di rapida esecuzione offre risultati tollerabili, definendo una metodica applicativa utilizzabile al pari di analoghe procedure di rilevamento indiretto applicabile in diversi ambiti, dall'architettura al territorio.
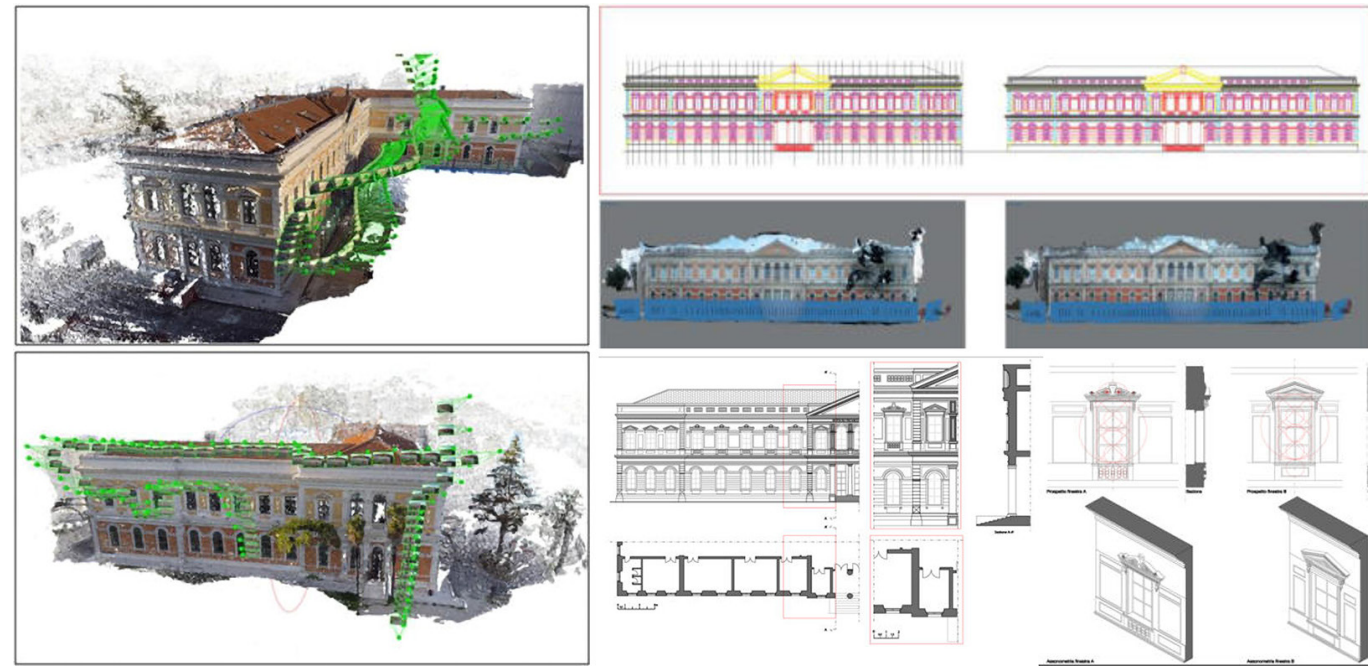

\section{Contenuti informativi e sperimentazioni per acquisizione da drone virtuale}

Il procedimento sperimentato consiste nella simulazione virtuale di un volo da drone, sfruttando i tour virtuali di Google Earth Pro. Seguendo un percorso prestabilito all'interno di una partizione di analisi suddivisa in macroaree sovrapposte, la camera virtuale viene inclinata a circa $45^{\circ} \mathrm{con}$ la finalità di estrarre i dati immagine necessari per le successive fasi di fotomodellazione.

Acquisendo dati da immagini Google bisogna ovviamente tener conto della possibile perdita di precisione dovuta alla ripetizione di una scansione fotogrammetrica manuale su un modello già generato attraverso le medesime procedure, perciò depositario di una percentuale di errore pregresso. A livello sperimentale, al fine di valutare l'entità dell'errore, è stata predisposta una fase di verifica, successiva alla generazione del modello dedotto da Google, in cui sono state messe a confronto le nuvole di punti generate. Un riscontro aggiuntivo è stato fornito dall'analisi dei dati cartografici da cui sono stati assimilati i punti fiduciali e le quote IGM che fungono da punti di controllo per misurare l'errore di rilevamento e restituzione insito nelle descritte metodologie, al fine di avere una serie di dati sull'errore medio, informazioni che sono utilizzate come parametri correttivi per ricalibrare il modello e georeferenziarlo. L'errore ammissibile è minimo, considerato sulla quota di volo e sulla risoluzione dell'ottica.

Analogamente ai piani di volo impiegati nei progetti di rilievo, la gestione del drone virtuale aderisce a due principali configurazioni, una 'foto-centrica' in cui il drone ruota intorno all'oggetto da rilevare, sempre ad inclinazione $45^{\circ}$, l'altra secondo un percorso a scacchiera, immaginando il path degli aerei di Google (fig. I). Spesso le due configurazioni possono es- 
sere integrate attraverso una precisa suddivisione in sottomoduli in cui vengono individuati precisi punti nodali intorno ai quali effettuare gli scatti con tecnica di presa foto-centrica, acquisendo da ogni lato una consistente mole di dati tridimensionali, sia relativi alla conformazione geomorfologica del terreno, sia riguardanti la disposizione e l'altezza del costruito. I numerosi fotogrammi ottenuti dal filmato del tour virtuale sono poi processati con il software Agisoft Metashape, al fine di ottenere mediante un metodo di allineamento dei pixel omologhi, una Dense Point Cloud. Da quest'ultima, sfruttando gli stessi punti come vertici, viene generata la mesh poligonale triangolata e texturizzata dell'intera area, sufficientemente dettagliata da ricalcare connotazioni plastiche analoghe al modello di riferimento.

\section{Comparazioni casi studio ed evoluzione della pipeline esecutiva}

La metodologia descritta offre modelli di studio idonei a ricostruire ed esplorare tridimensionalmente situazioni territoriali complesse attraverso sistemi di rilevamento integrato e software capaci di offrire possibilità di interazione virtuale applicabili in ambiti diversificati. Da alcuni anni nei Corsi di Rilevamento di Architettura e Ingegneria si portano avanti ricerche e sperimentazioni finalizzate al miglioramento di questa pipeline esecutiva e metodologica, con specifiche applicazioni che vanno dalla scala territoriale a quella architettonica, coinvolgendo manufatti storici, come l'istituto ottocentesco del Tito Acerbo a Pescara [Palestini 2018, pp. 821-828], architetture urbane come il rilievo degli istituti scolastici del secondo dopoguerra [Palestini, 2019a, pp. 937-944], di opere infrastrutturali e del contesto ambientale come nel caso studio dei bacini fluviali [Palestini 20 I 9b, pp. 543-550 ] (figg. 2, 3). Le esperienze nel loro insieme sono servite a far mettere a punto soluzioni tecniche riferibili alla scelta di formati, di software e tra questi gli algoritmi di calcolo più consoni a ottenere il
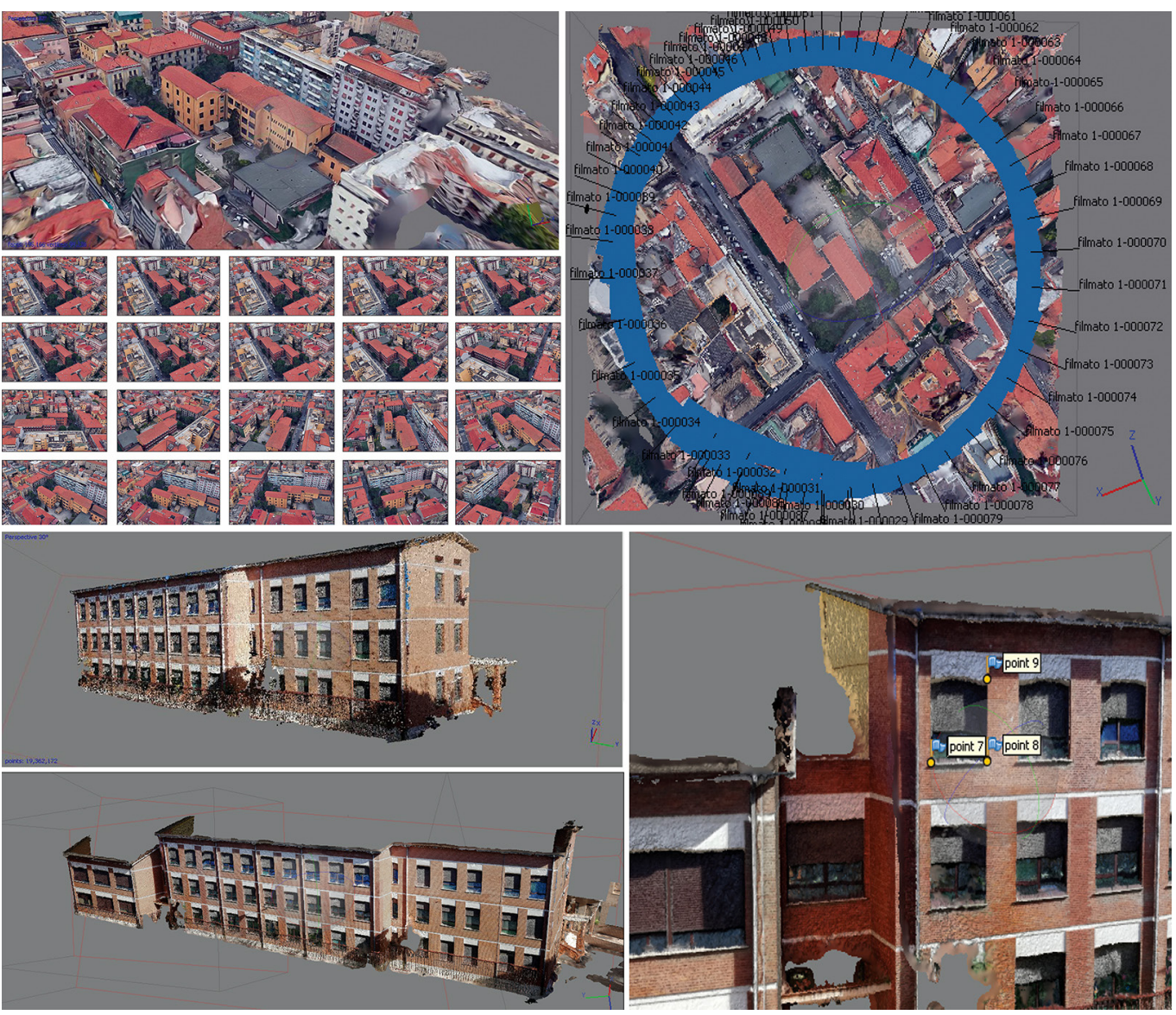


\section{Camera Locations}
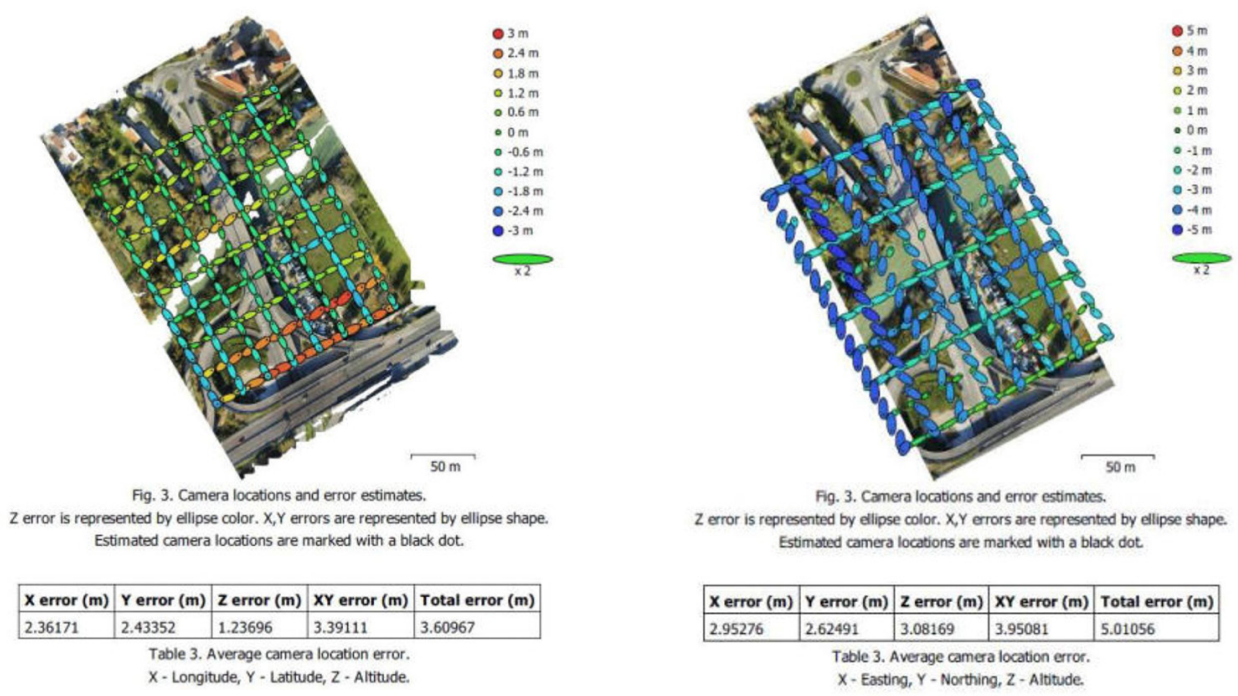

\section{Ground Control Points}

Fig. 4. Camera Location e Ground Control Point report, rilevamenti porzione bacino fluviale Aterno-Pescara (20|9).

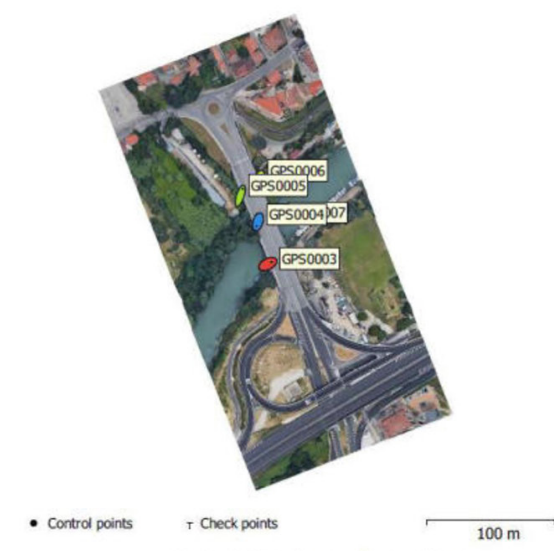

Fig. 3. GCP locations and error estimates. $Z$ error is represented by ellipse color. X,Y errors are represented by ellipse shape. Estimated GCP locations are marked with a dot or crossing.

\begin{tabular}{|l|l|l|l|l|l}
\hline Count & X error $(\mathrm{cm})$ & Y error $(\mathrm{cm})$ & Z error $(\mathrm{cm})$ & XY error $(\mathrm{cm})$ & Total $(\mathrm{cm})$
\end{tabular}

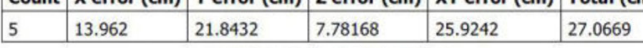
Table 3. Control points RMSE.

$X$ - Easting, $Y$ - Northing, Z - Altitude.
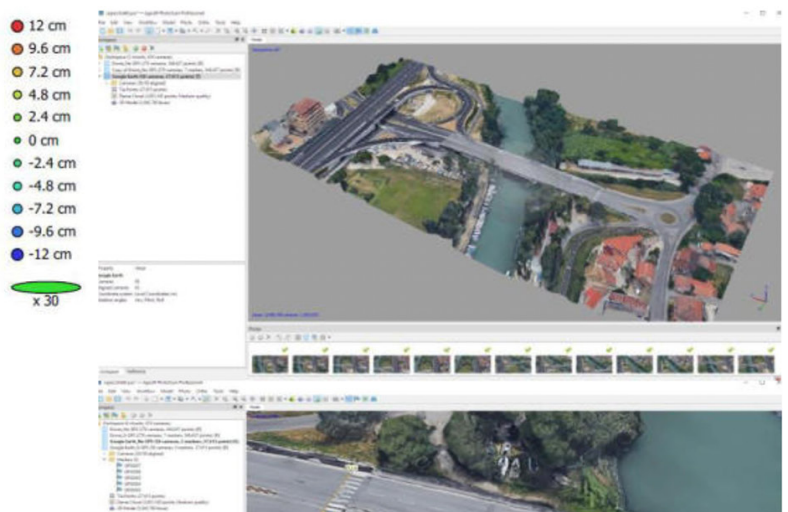

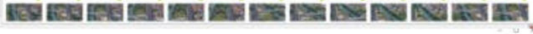

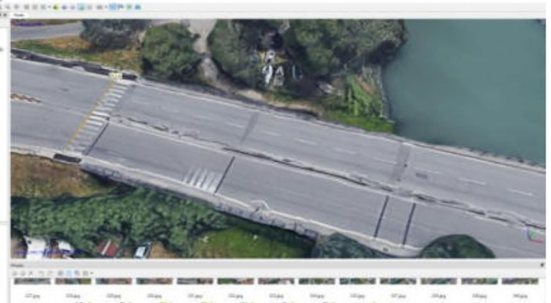

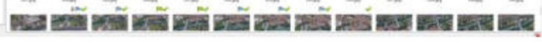

risultato ottimale, delineando la struttura del workflow esecutivo veloce e stabile, adeguato ad ottenere un modello metrico-proporzionale il più possibile fedele al campione reale.Tutti i casi studio presi in esame condividono un'analoga metodologia operativa: l'utilizzo della fotogrammetria terrestre e aerea, coadiuvata da sistemi Unmanned-Aerial-Vehicle (UAV), a cui si aggiunge il rilievo fotogrammetrico sperimentale effettuato da drone virtuale. I risultati ottenuti nelle varie esperienze sono stati messi a confronto per controllare l'errore, il livello di accuratezza e la comparabilità dei risultati che ne derivano, utili per definire il raggiungimento delle finalità richieste.

Nella ricostruzione digitale di diversi casi studio, tra cui una serie di istituti scolastici localizzati in aree centrali e periferiche della città, le metodologie descritte si sono rivelate utili considerando gli esiti ottenuti, la velocità di acquisizione ed elaborazione, nonché l'accuratezza. II piano di volo è stato strutturato mediante app per smartphone e la fase di volo ed acquisizione aerea di immagini è avvenuta quasi completamente in automatico, fornendo dei dati con un errore ammissibile centimetrico considerato sulla quota di volo e sulla risoluzione dell'ottica. 
Fig. 5. Rilevamenti integrati, confronto drone reale Istituto scolastico Borgo Marino (2019)
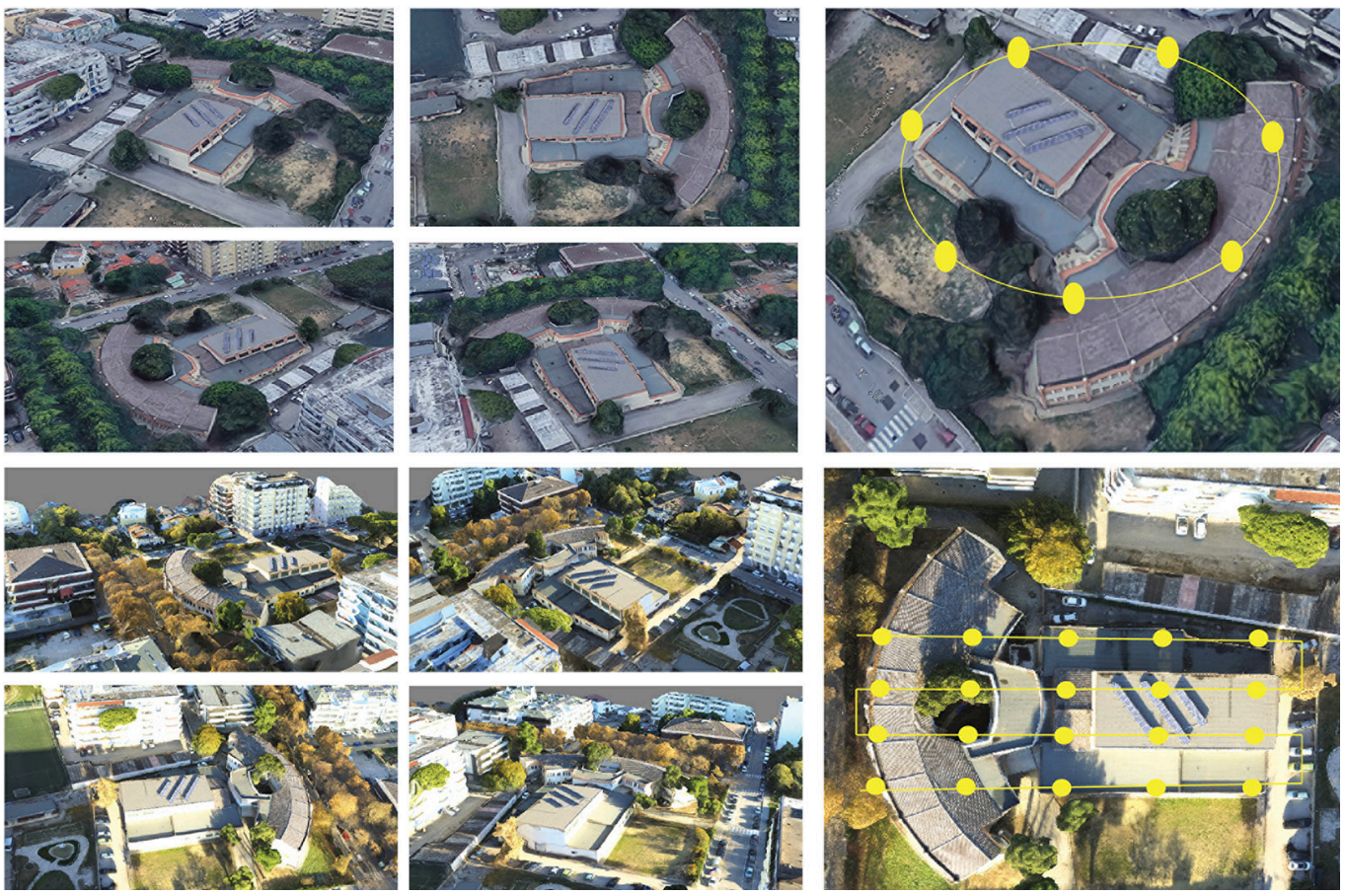

Fig. 6. Fasi di acquisizione e elaborazione dati (sinistra) ponte Dom Luis a Porto e (destra) Trinity bridge a Manchester bridge a Manchester
(DAD marzo 2020)
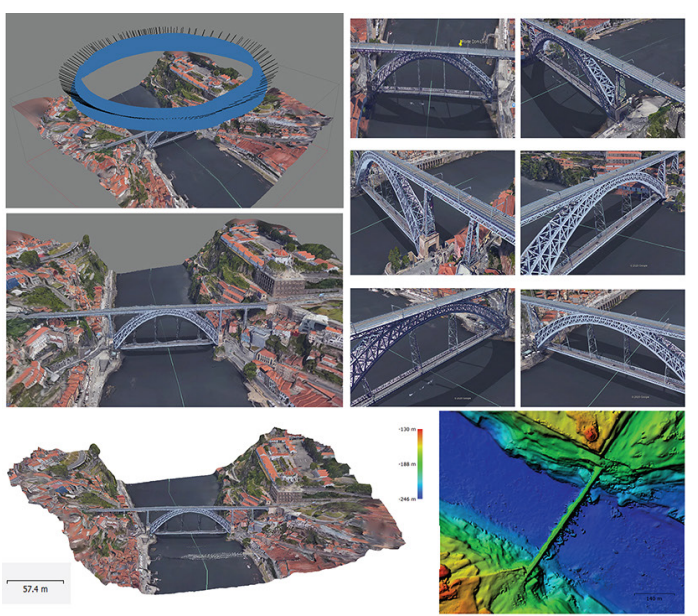

Le immagini aeree da drone sono poi state integrate dagli screen-shot acquisiti durante il tour virtuale pianificato sulla piattaforma Google Earth Pro, consentendo in parallelo una estrapolazione dei dati plastico-tridimensionali delle porzioni urbane esaminate. Le immagini aeree da drone e quelle derivanti da Google Earth hanno fornito i confronti desiderati, permettendo verifiche sulle medesime porzioni acquisite con i due sistemi operativi.

Le operazioni di analisi e acquisizione dati applicate a porzioni più ampie di territorio come quelle fluviali hanno permesso di focalizzare l'attenzione sulle criticità di un ambiente complesso con connotazioni eterogenee che variano da aree prevalentemente naturalistiche a zone fortemente antropizzate. I rilevamenti condotti sul percorso del fiume Pescara-Aterno hanno offerto la possibilità di effettuare comparazioni dirette, corredate da dati numerici, tra la nuvola di punti generata dalle immagini acquisite dal drone reale e quella nata attraverso l'escamotage del drone virtuale.

Nello specifico la prima differenza che viene fuori dai modelli è la misura in scala. II drone reale permette di scattare fotografie con informazioni di posizione e specifiche tecniche dell'ottica, 
Fig. 7. Modello 3d ottenuto da rilevamento e fotomodellazione del Millenum bridge a Londra.

Fig. 8. Fasi di acquisizione e elaborazione dati pont The Helix, Singapore Marina Bay (DAD marzo 2020).
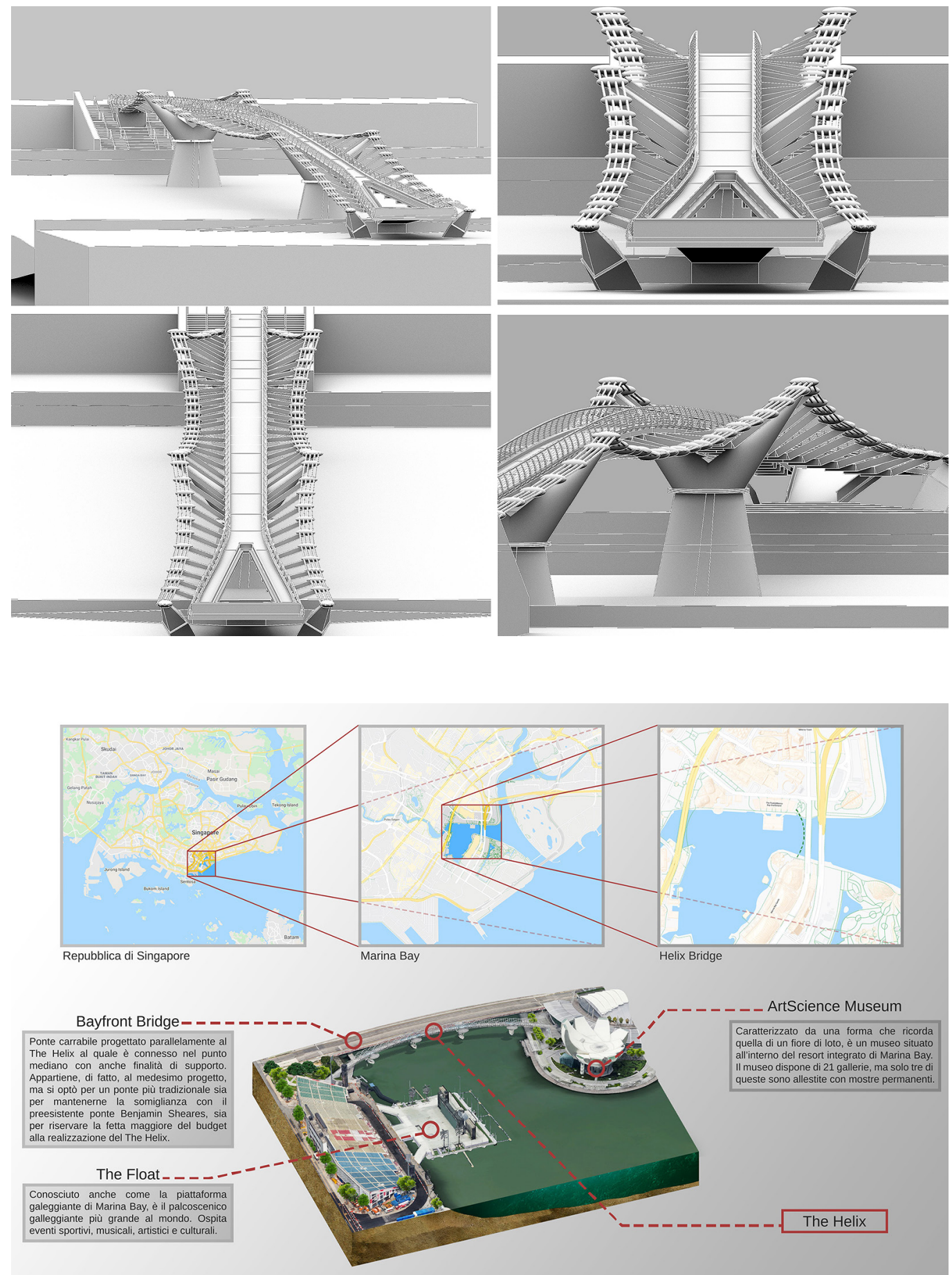

consentendo al software di creare un modello già in scala. Diversamente accade per i dati derivanti dalle nuvole punti restituite da Google perché risultano costituite da immagini prive di metadati. Il software genera quindi un primo modello proporzionato al quale bisogna associare misure di controllo per scalare il modello. L'errore è owiamente legato alla risoluzione delle immagini, minore è il dettaglio, maggiore sarà lo scarto di errore. Per valutare l'entità dell'errore sono stati presi punti d'appoggio, acquisiti con GPS di precisione, all'interno delle nuvole create, generando così dei marcatori come punti assoluti su cui vincolare il modello. In sostanza, rilevando e posizionando almeno 4 punti reali e materializzandoli all'interno della nuvola generata, induciamo il programma a far coincidere gli stessi punti virtuali con quelli presi materialmente. Questa operazione 

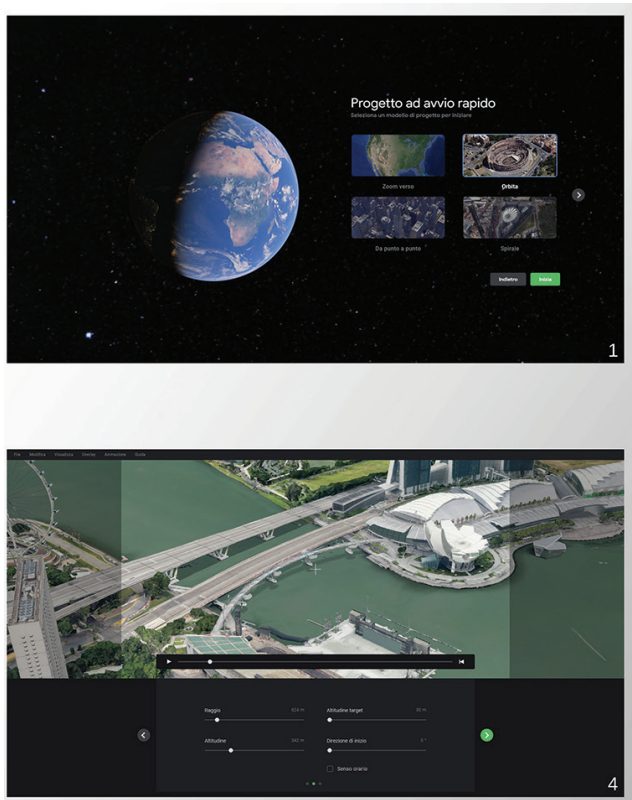

È possibile effettuare delle riprese aeree "virtuali" sfruttando le carte geografiche e i modelli tridimensionali di Google. Per la creazione del piano di volo possiamo sfruttare il sofisticato tool, sempre di proprietà di Google, Earth Studio.

1. Accedere al sito https://earth.google.com/studio/.

2. Scegliere, tra quelle offerte, la tipologia di piano di volo che meglio soddisfi le nostre esigenze (in questo caso l'orbita).
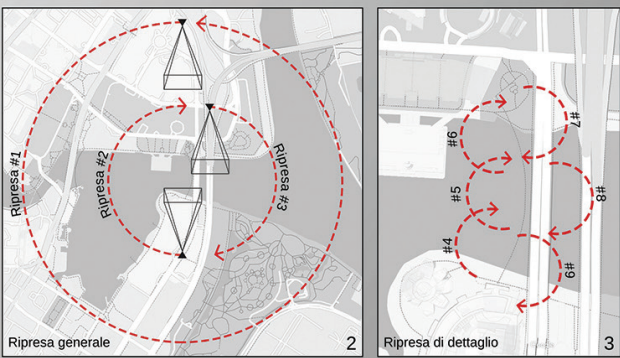

3. Definire il centro dell'orbita.

4. Impostare i parametri relativi alla quota, l'inclinazione della visuale, il raggio di copertura e, infine, la durata del tempo di volo, espressa in secondi.

5. Impostare i parametri relativi al numero dei fotogrammi da acquisire e la relativa dimensione.

6. Procedere con l'acquisizione delle immagini.
Figg. 9, I0. Fasi di acquisizione e elaborazione dati ponte The Helix, Singapore Marina Bay (DAD marzo 2020)

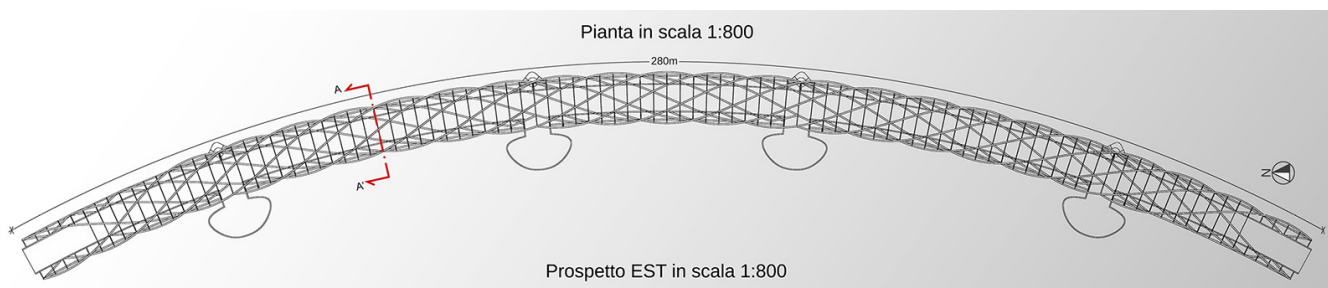

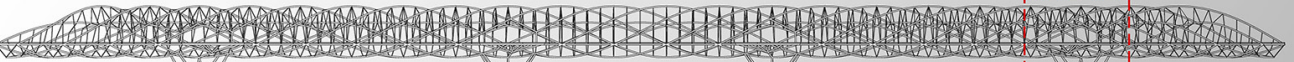

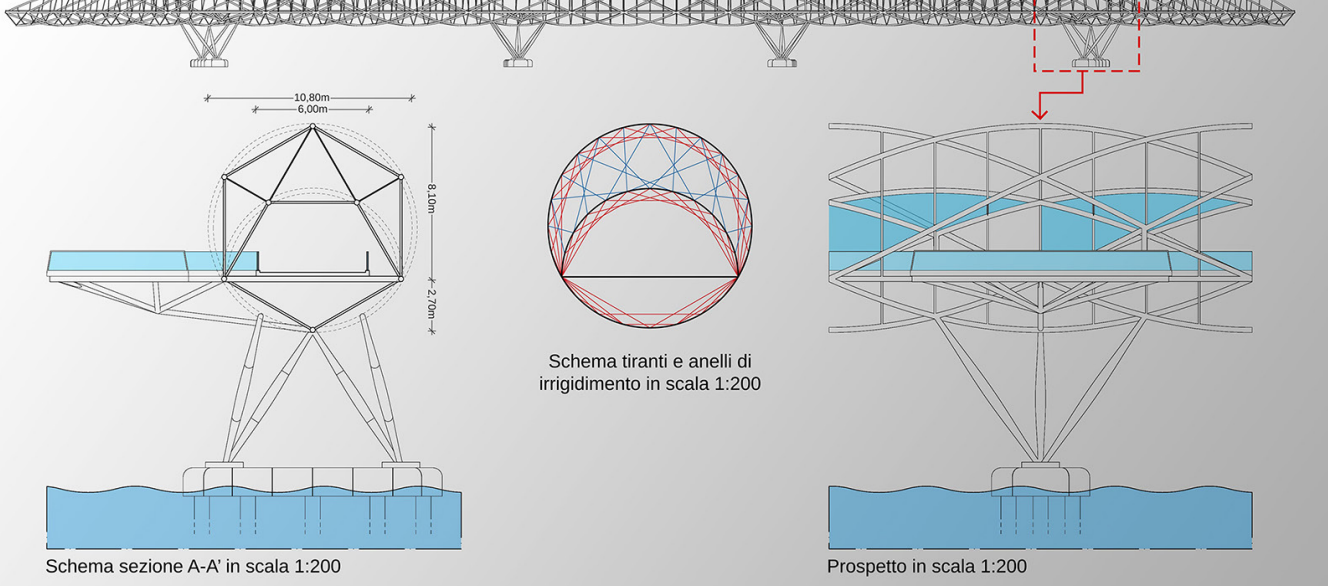

genererà un errore, dovuto all'adattamento correttivo che il software applicherà al modello per compilarlo attraverso i marcatori stabiliti. I risultati messi a confronto evidenziano che il modello generato dalle immagini prese da Google Earth soffre ovviamente di limitazioni come la perdita di risoluzione, la mancanza di georeferenziazione e nessun dato exif della focale (fig. 4). Nonostante ciò, il software elabora la nuvola di punti dalla sequenza di 60 screenshot manuali simulando la griglia del piano di volo, dimostrando che è possibile applicare il fattore di scala e le coordinate GPS prese fisicamente sulla nuvola generata da Google. Una volta applicate le coordinate GPS è possibile ricavare l'errore dovuto allincertezza nel rapporto tra la densità dei pixel e il posizionamento manuale dei marcatori GPS applicati sulle immagini fotografiche da elaborare. 


\section{Esperienze di rilevamento nella didattica a distanza}

Dai confronti descritti derivano le applicazioni sperimentate nella didattica a distanza, avviate come soluzione emergenziale nel primo lockdown con il Dpcm del 4 marzo 2020. La necessità di non interrompere gli insegnamenti universitari ha comportato uno sforzo organizzativo notevole soprattutto per le materie applicative e laboratoriali che richiedono un'interazione grafica in presenza come le fasi di acquisizione dati tipiche del rilevamento. Sembrava impossibile far esercitare i ragazzi nei procedimenti operativi richiesti nelle canoniche operazioni mensorie, eppure nonostante le criticità dell'immersione forzata in questo sistema di partecipazione online, svolta principalmente in streaming, mettendo in atto le suddette sperimentazioni di rilevamento 'virtuale' si sono ottenuti dei risultati apprezzabili, sui quali vale la pena di riflettere (fig. 5).

Nel corso di Ingegneria sono stati assegnati come tema di studio una serie di ponti contemporanei, scelti in base alle caratteristiche tecniche e alla copertura tridimensionale delle riprese di Google Earth Pro. Si riportano a tal proposito alcuni lavori che a titolo esemplificativo mostrano la metodologia seguita dagli allievi, tra questi il rilevamento del ponte storico Dom Luis costruito alla fine dell'Ottocento in Portogallo. II ponte è frutto di un concorso per la realizzazione di un collegamento tra le due sponde del fiume Duero nella città di Porto che presenta un forte salto di quota orografico tra i nuclei urbani da connettere. La scelta è stata quella di edificare un ponte ad arco su due livelli impiegando una struttura metallica, ardita rispetto all'epoca di costruzione, affidata a Thèophile Seyrig, un discepolo di Gustave Eiffel, che redige l'avanguardistico progetto.

II ponte Dom Luis è un ponte ad arco costruito su due impalcati in ferro, quello superiore lungo circa $385 \mathrm{~m}$ a $62 \mathrm{~m}$ di altezza dal fiume e quello inferiore lungo $172 \mathrm{~m}$ a $10 \mathrm{~m}$ di altezza dal fiume, entrambi sostenuti da un arco di ferro con una campata di $172 \mathrm{~m}$ con cinque pilastri intermedi ancorati ai due argini tramite pilastri in muratura. L'esempio in questione è risultato interessante dal punto di vista del rilevamento per la plasticità della situazione orografica e per la restituzione del disegno della struttura metallica di cui si compone. Le sequenze operative mostrano le fasi di acquisizione dati e di elaborazione con l'allineamento delle immagini scattate da drone virtuale, seguite dalla configurazione di nuvole sparse e dense e dai relativi modelli 3d e DEM, da cui derivano l'orto-mosaico e le rappresentazioni tridimensionali e bidimensionali. Altri casi riguardano alcuni ponti di Calatrava tra cui ilTrinity
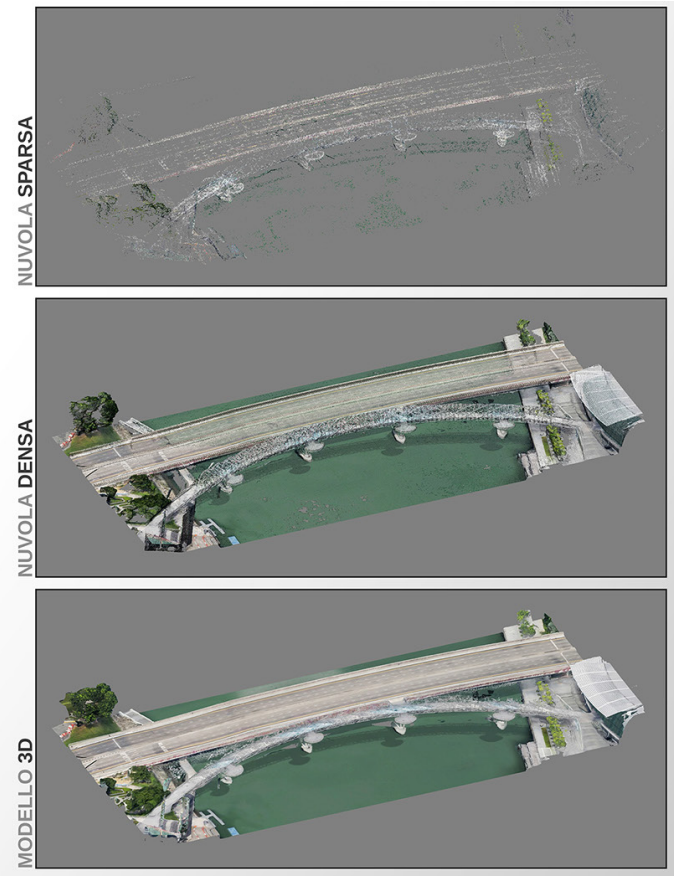
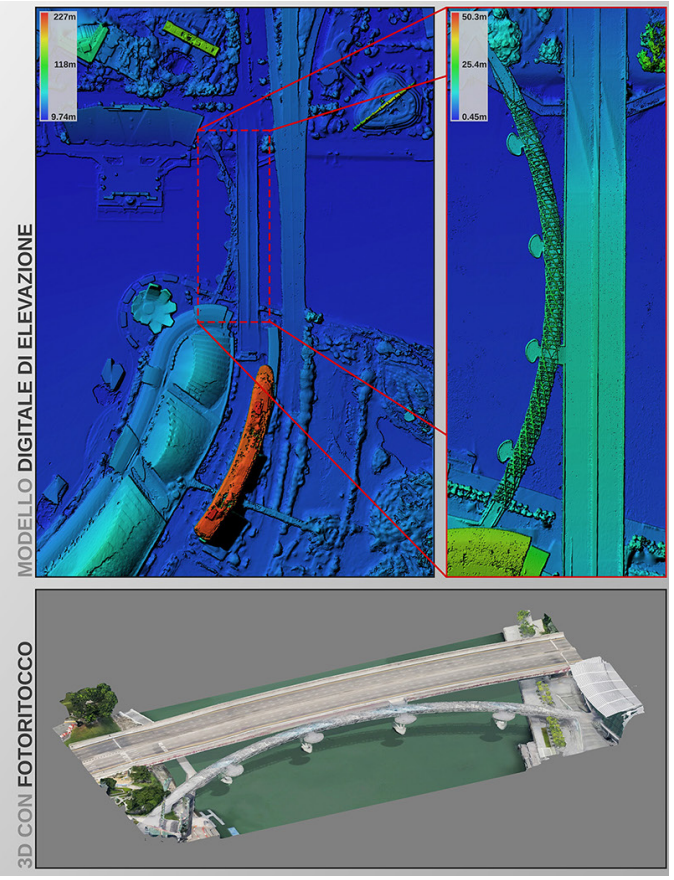
Bridge a Manchester e Bac de Roda a Barcellona che associano l'aspetto formale alla complessità strutturale delle componenti progettuali (fig. 6).

Un'ulteriore sperimentazione è stata condotta integrando i rilevamenti con la modellazione tridimensionale come nel caso del Millennium Bridge di Norman Foster a Londra che collega la cattedrale di St. Paul (a nord) con il Globe Theatre e la Tate Modern Gallery fornendo l'innovativo collegamento tra le due sponde del Tamigi (fig. 8).

Analogo procedimento ha riguardato il rilevamento del complesso che collega le due aree del Marina Bay di Singapore, frutto di una progettazione internazionale vinta dagli studi di architettura Cox Group e Architects 6 I e dallo studio di designer Arup, che hanno riqualificato l'area con la costruzione del ponte pedonale noto come Double Helix Bridge composto da una doppia elica in acciaio ispirata alla struttura del DNA. Nella fase di acquisizione è stato possibile scegliere il piano di volo virtuale, definire il centro dell'orbita, impostare i parametri relativi alla quota, all'inclinazione della visuale e del raggio di copertura stabilendo i parametri relativi al numero e alla dimensione dei fotogrammi che si ritengono necessari per elaborare le fasi del rilevamento image based (figg. 8-I I). Per quanto riguarda il corso di Architettura, in analogia con le sperimentazioni in precedenza trattate, sono state presi in considerazione gli edifici e le strutture scolastiche del secondo Novecento scendendo ad una maggiore scala di dettaglio.

\section{Conclusioni}

Traendo spunto dalla diffusione dei sistemi di rilevamento low cost che nel corso degli anni sono stati progressivamente implementati, per la loro immediatezza esecutiva correlata al favorevole riscontro economico, si è testato un sistema alternativo applicabile per rilevamenti speditivi, verificabile e implementabile con metodologie integrate in base alle finalità da raggiungere.

Si è concretizzata così la necessità di rendere operative tali metodologie comparandone i risultati per effettuare letture ambientali e ricostruzioni 3D attraverso restituzioni che coinvolgono l'uso sperimentale di software specifici per ottenere depht maps di modelli territoriali compatibili con quelli reali, incrociando free open data ottenuti dalle ricostruzioni fotogrammetriche di Google Earth Pro e informazioni fornite in loco da strumentazioni RPAS (Remoted Piloted Air System) che si avvalgono delle metodologie image based per rilevamenti open source tra reale e virtuale (fig. 12).

Google, vera e propria potenza nel settore della digital industry per capacità di investimento, di marketing e comunicazione, ha puntato a livello globale sulle tecniche più innovative di Remote Sensing spendendo molto impegno in soluzioni non espressamente riconducibili al modello Geomatico ma che funzionano come una sorta di acceleratore creativo per operazioni diversificate, da quella del rilievo territoriale, alla progettazione architettonica e all'utilizzo dei dati per finalità scientifiche o di ricerca. La descritta sperimentazione, adottando una pipeline esecutiva alternativa di facile attuazione e alla portata di tutti, ha permesso di operare effettuando operazioni di foto modellazione sfruttando immagini 3d elaborati e pubblicati in Google Earth Pro. II procedimento altamente low cost consente di ottenere velocemente un primo modello di studio semi dettagliato da impiegare in operazioni di rimodellazione manuale, per creare sfondi territoriali $3 \mathrm{~d}$ da impiegare per rendering o per definire ambientazioni urbane utili per l'inserimento di progetti architettonici.

In conclusione, il contributo pone riflessioni sulle possibili implementazioni dei contenuti informativi di Google da impiegare nello specifico nella didattica in remoto.

Mediante la metodologia descritta è stato possibile ottenere rilevamenti e modelli di studio idonei alla ricostruzione ed analisi $3 \mathrm{~d}$ di ambiti territoriali attraverso sistemi di rilevamento image based. La semplicità di utilizzo del workflow permette un facile impiego nella didattica a distanza dando la possibilità agli studenti, come documentato negli esempi descritti, di sperimentare la gestione dei dati per operazioni di rilevamento e rappresentazioni architettoniche. L'integrazione con software dedicati può consentire inoltre la possibilità di far interagire applicazioni metodologiche virtuali declinabili a diverse scale architettoniche ed urbane. 
Fig. I 2. Lezione DAD: Fasi di acquisizione dat a distanza con drone virtuale (ottobre 2020)

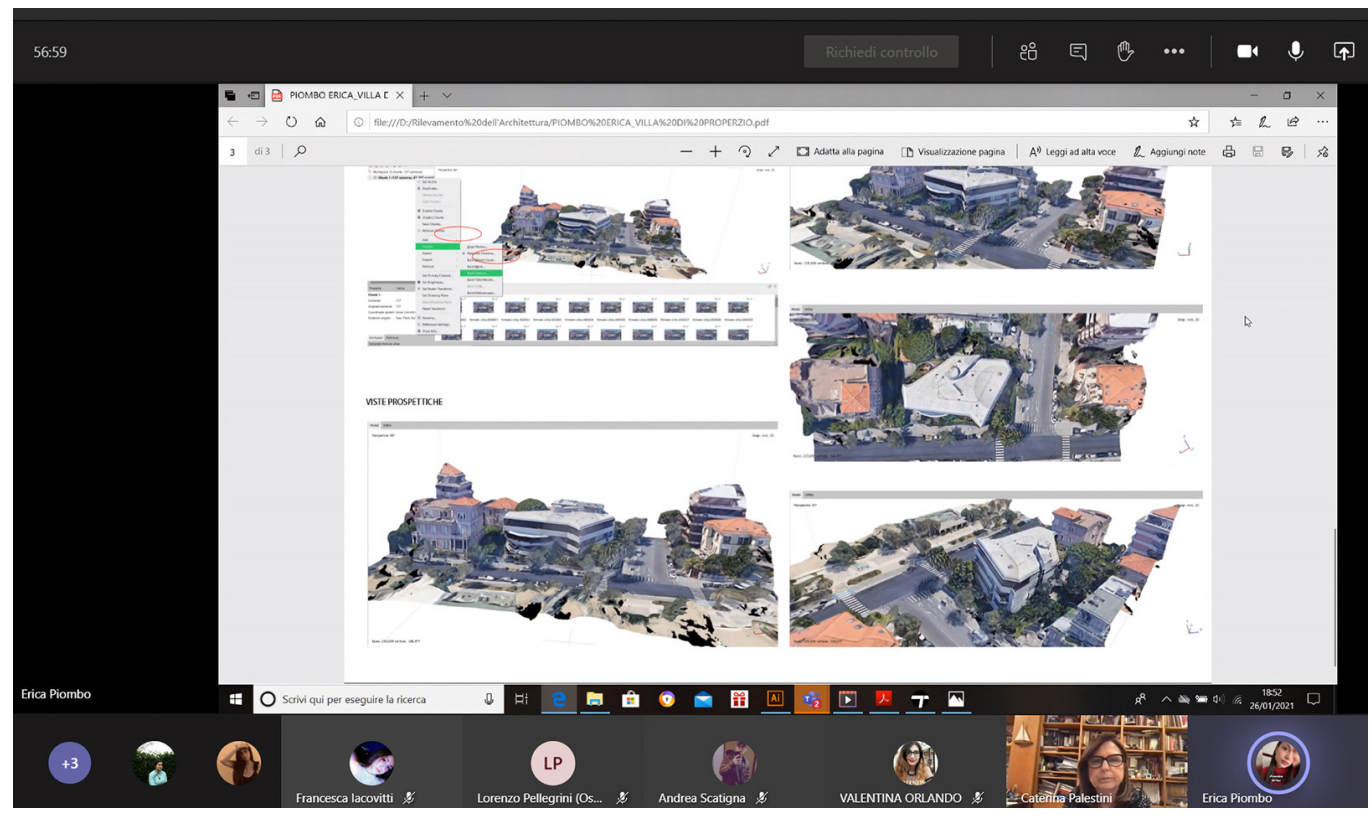

Riferimenti bibliografici

Bianchini C. (20I4). Survey, Modeling, Interpretation as multidisciplinary components of a knowledge system. In SCIRESIT, n. 4 (I), pp. $15-24$

Cundari C. (1984). Fotogrammetria Architettonica. Bologna: Kappa.

De Luca L. (20 I I). La Fotomodellazione Architettonica. Palermo: Flaccovio Editore.

Magallanes G., et al. (20 18). Modelling of collective movement in immersive environments. In International Archives of the Photogrammetry, Remote Sensing and Spatial Information Sciences, vol. XLII-4, pp. 397-402.

Napolitano R.K., Scherer G., Glisic B. (2018).Virtual tours and informational modeling for conservation of cultural heritage sites, In Journal of Cultural Heritage, n. 29, pp. 123- 129.

Palestini C., Basso A. (2019a). Cultural Projects And Geomatic Surveys for the Resilience of School Heritage. In International Archives of the Photogrammetry, Remote Sensing and Spatial Information Sciences, vol. XLII-2MI I, pp. 937-944.

Palestini C., Basso A. (2019b). 3D Detection and reconstruction in river basins. In International Archives of the Photogrammetry, Remote Sensing and Spatial Information Sciences, vol. XLII-2N9, pp. 543-550.

Palestini C., Basso A. (2020). The UAV Survey of the Valvense Complex in Corflnlo, comparison between two photomodelling methods. In S. Barba et al. (Ed.). D-SITE Drones - Systems of Information on Cultural Heritage for a spatial and social investigation, pp. 274-283. Pavia: Pavia University Press.

Palestini C., Basso A., Graziani L. (2018). Integrated photogrammetric survey and BIM modeling for the protection of Schoo Heritage, applications on a case study. In International Archives of the Photogrammetry, Remote Sensing and Spatial Information Sciences, vol. XLII-2, pp. $821-828$

Santagati C., Inzerillo L., Di Paola F. (20I3). Image-based modeling techniques for architectural heritage 3d digitalization: limits and potentialities. In International Archives of the Photogrammetry, Remote Sensing and Spatial Information Sciences, vol. XL-5/ W2, 20, pp. 550-560.

Autori

Caterina Palestini, Università degli Studi "G. d'Annunzio" di Chieti e Pescara, palestini@unich.it Alessandro Basso, Libera Università di Bolzano, alessandro.basso@unibz.it

Per citare questo capitolo: Palestini Caterina, Basso Alessandro (2021). Rilievo a distanza: una metonimia per sperimentazioni tra didattica e ricerca/Remote sensing: a Metonym for Experimentation between Teaching and Research. In Arena A., Arena M., Mediati D. Raffa P. (a cura di). Connettere Un disegno per annodare e tessere Linguagoi Distanze Tecnologie. Atti del $42^{\circ}$ Convegno Internazionale dei Docenti delle Discipline della Rappresentazione/Connecting Drawing for weaving relationship. Representation Disciplines Teachers. Milano: FrancoAngeli, pp. 2513-2534. 


\title{
Remote Sensing: a Metonym for Experimentation between Teaching and Research
}

\author{
Caterina Palestini \\ Alessandro Basso
}

\section{Abstract}

Investigating the abstract for the concrete in the rhetorical dualism between cause and effect, refers to the experimentation carried out for distance learning in which, since it is not possible to carry out the usual surveying operations in presence with the students, an operational methodology was defined centred on experiences of data acquisition from information content using virtual simulations. The experience is based on previous scientific research and experiments that have compared drone acquisitions with virtual tours that capture images from the Google Earth Pro information platform. The low-cost procedure makes it possible to quickly obtain a study model to be used as a basis for survey operations by remodelling, for the creation of representations derived from online acquisitions. As a methodological premise, we will illustrate and compare the applications carried out in two cognitive areas on an architectural and territorial scale, providing results and criticalities obtained through these low-cost systems, and then go on to describe the work obtained from the teaching model implemented during the emergency phase of the pandemic, which forced us to suddenly abandon the usual operational phases of the survey to engage in distance learning, which is not easy due to the specific nature of the discipline. In short, the contribution proposes operational reflections from which to explore the opportunities offered by technology, the analytical and representative potential of digital languages in the field of distance learning.

\section{Keywords}

sensing, low-cost methodologies, distance learning, digital languages, photomodelling.

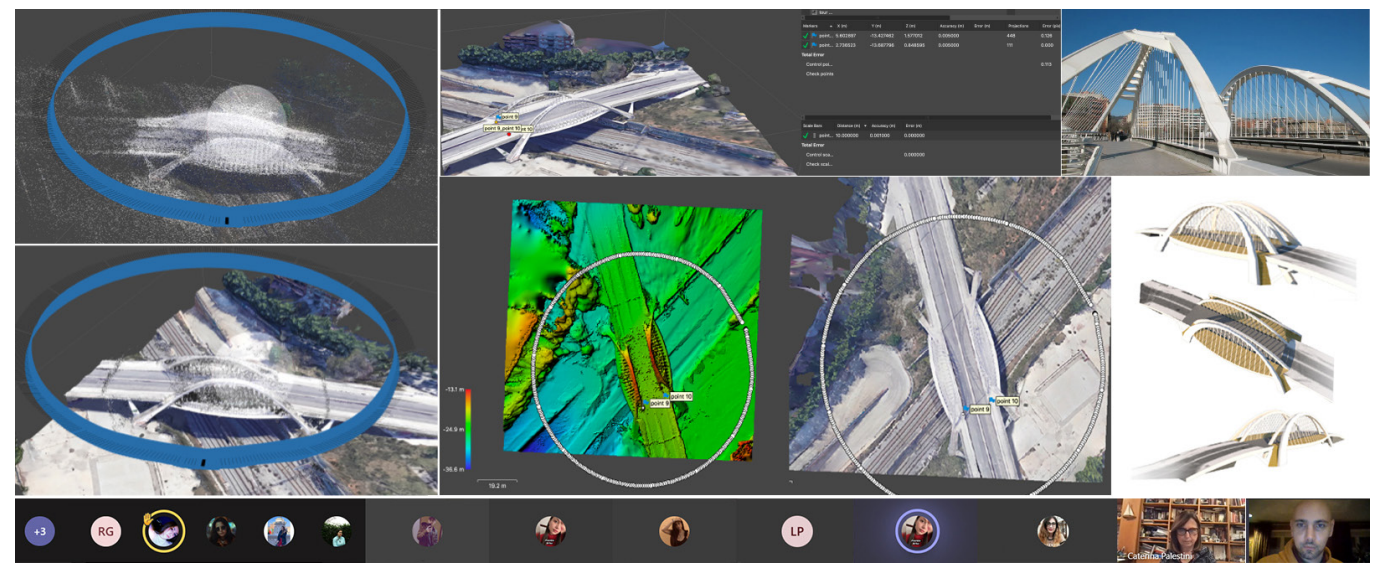




\section{Introduction}

The contribution exposes an operational methodology that adopts an alternative data acquisition mode through which photomodelling operations are captured on $3 \mathrm{~d}$ models processed by the Google Earth Pro platform. The low-cost procedure makes it possible to quickly obtain an initial semi-detailed study model to be used as the basis for manual and retropological remodelling operations, for the creation of 3D spatial models, for renderings or for the definition of georeferenced settings in which the surveys are inserted. Google Earth, born as an online tool to support a web directory based on a popular approach, soon became a geographical survey tool with GIS ambitions, so much so that it is used by companies and organizations that use such data in their projects. The contemporary approach connected to the dynamics of web 2.0 looks at the creation of information containers, spatial in nature and not directly managed by the user, consequently most of the technological players in the GIS field (Autodesk, Bentley Systems, Intergraph, ESRI, Bing 3d etc.) end up following the navigation interface identified by Google Earth and Maps, with its famous three-dimensional globe and the convenient satellite zoom system. Moreover, for some years now, Google has been restyling its interactive exploration dynamics, implementing interesting graphic updates that make consulting the app even more useful.

One of these upgrades is the use of high-detail photogrammetry. Using special aircraft, equipped with 5 cameras with wide-angle lenses arranged at the four cardinal points and perpendicular to the ground plane, 3D photogrammetric scanning acquires data through certain zigzag shooting paths. Similarly to the procedures used for aerial photogrammetric surveys carried out with a metric camera, shots are taken with regular sequences, in order to obtain an overlap of about $80 \%$ with each other. The photographic data are then optimised and photo-retouched by the Google staff, partly using automatic graphic procedures, in order to normalise the chromatic aspect, the digital noise and possible artefacts that tend to homogenise the photographic data. These procedures make it possible to reduce any mesh deformation errors in the subsequent self-modelling phases. The navigable model in real time returns in detail in 3D huge portions of the urban territory, an important data resource that can be used for multiple purposes.

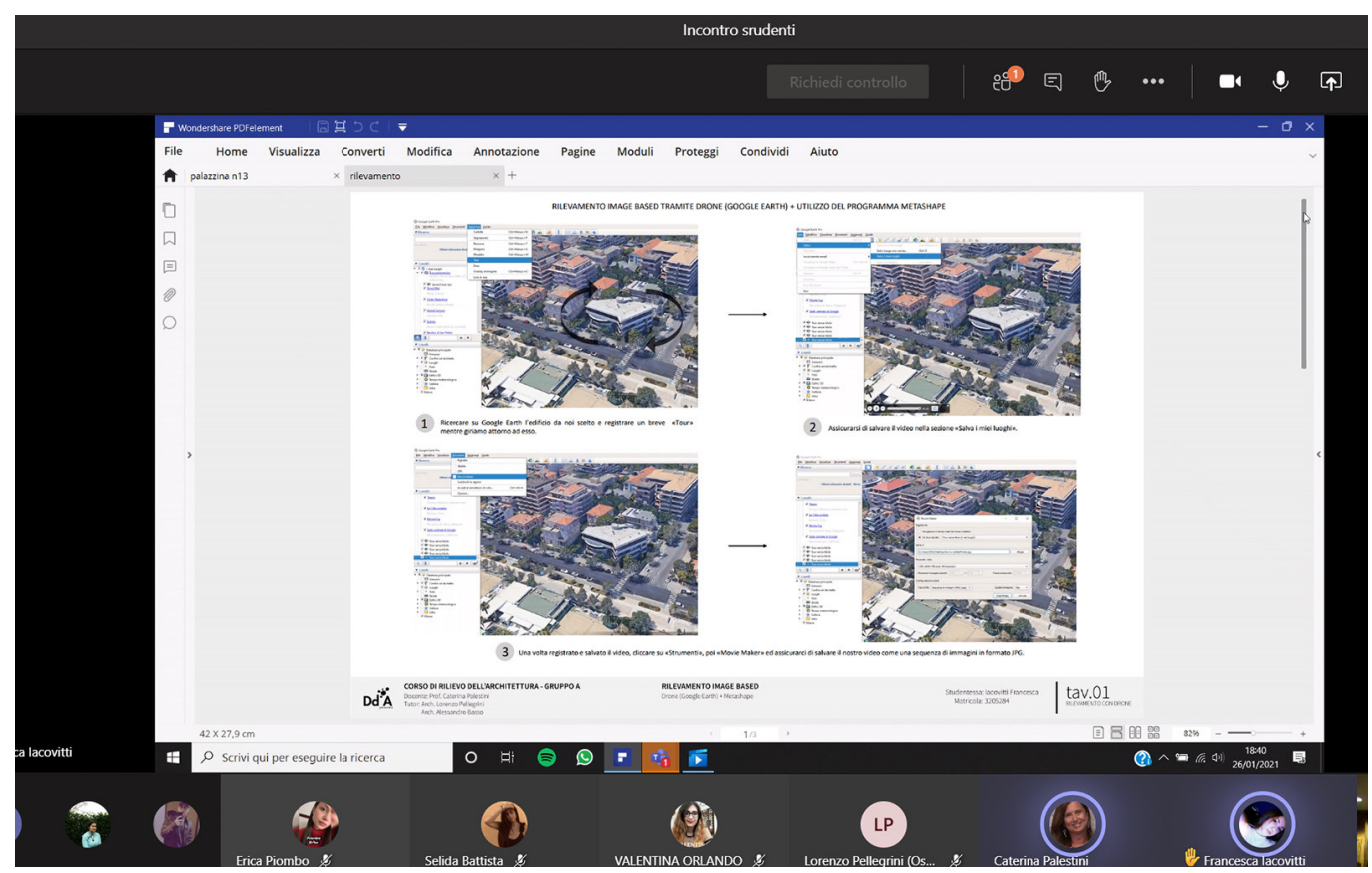


During the months in which the pandemic developed, the idea of using these information containers was born, employing an alternative experimental methodology that allowed the students to carry out a 3D photogrammetric survey without using drones or Lidar instruments for aerial surveys, bypassing the fundamental and necessary phase of on-site data acquisition. The students were thus directed towards the application of the methodology that can be carried out remotely, pursuing the objective of considering partitions of three-dimensional territory as the object of study from which to obtain immediate visual results. The system also allowed the rapid acquisition of metric data for scale restitution, which provided acceptable solutions given the lack of specific instrumentation. The rapid execution procedure offers tolerable results, defining an application method that can be used in the same way as similar indirect survey procedures, applicable in various fields, from the architecture to the territory.
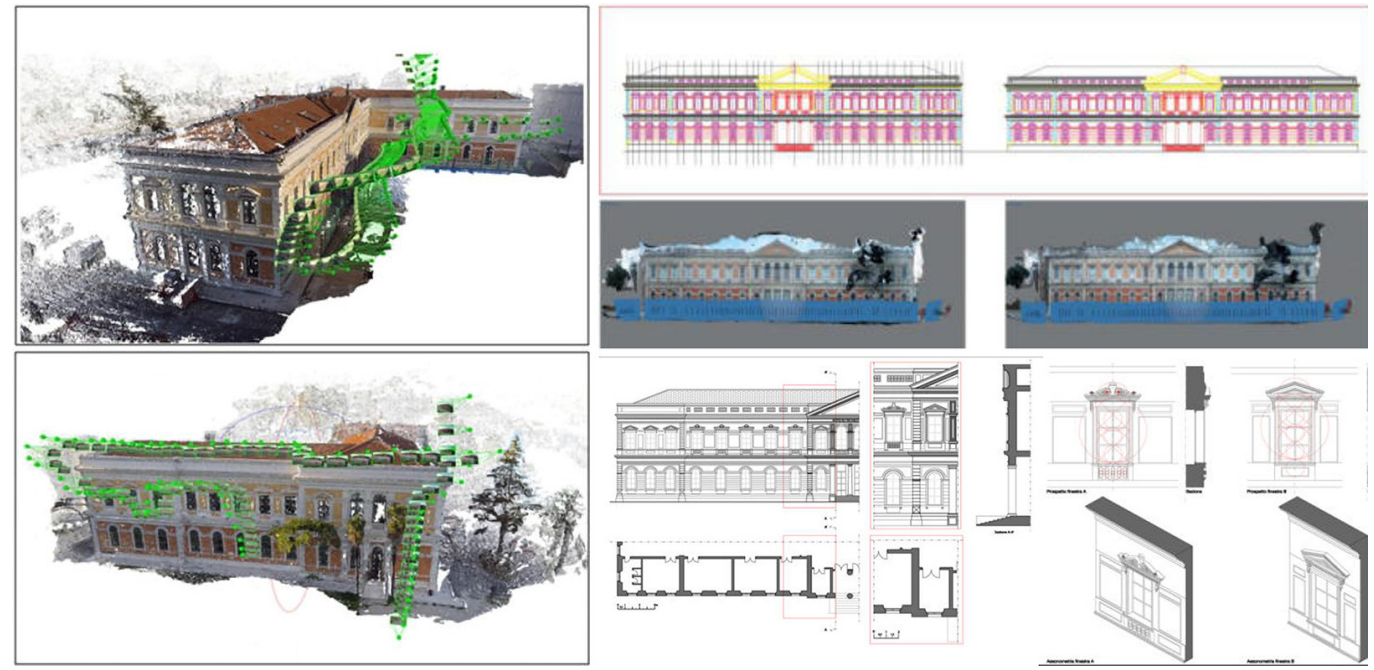

\section{Information content and experiments for virtual drone acquisition}

The experimented procedure consists in the virtual simulation of a drone flight, using the virtual tours of Google Earth Pro. Following a predefined path within an analysis partition divided into overlapping macro-areas, the virtual camera is tilted at about $45^{\circ}$ in order to extract the image data necessary for the subsequent photomodelling phases.

When acquiring data from Google images, it is obviously necessary to take into account the possible loss of precision due to the repetition of a manual photogrammetric scan on a model that has already been generated using the same procedures, and therefore has a percentage of previous error. At an experimental level, in order to evaluate the entity of the error, a verification phase was set up, following the generation of the model deduced by Google, in which the generated point clouds were compared. Additional feedback was provided by the analysis of the cartographic data from which the fiducial points and IGM elevations were assimilated, acting as control points to measure the error of detection and restitution inherent in the described methodologies, in order to have a series of data on the average error, information that is used as corrective parameters to recalibrate the model and georeference it. The permissible error is minimal, considering the flight altitude and the resolution of the optics.

Similarly to the flight plans used in surveying projects, the management of the virtual drone adheres to two main configurations, one 'photo-centric' in which the drone rotates around the object to be surveyed, always at a $45^{\circ}$ angle, the other following a chessboard path, imagining the path of Google's planes (fig. I). Often, the two configurations can be integrated by means of a precise subdivision into sub-modules in which precise nodal points are 
identified around which the photos are taken using a photo-centric technique, acquiring a considerable amount of three-dimensional data from each side, both relative to the geomorphological conformation of the terrain, and regarding the layout and height of the buildings. The numerous frames obtained from the film of the virtual tour are then processed with the Agisoft Metashape software, in order to obtain, through a method of alignment of homologous pixels, a Dense Point Cloud. From the cloud, using the same points as vertices, the triangulated and textured polygonal mesh of the entire area is generated, detailed enough to trace plastic connotations similar to the reference model.

\section{Case study comparisons and evolution of the implementation pipeline}

The methodology described offers study models suitable for reconstructing and exploring complex three-dimensional territorial situations through integrated survey systems and software capable of offering possibilities of virtual interaction applicable in different areas. For some years now, research and experimentation aimed at improving this executive and methodological pipeline has been carried out in the Architectural and Engineering Surveying Courses, with specific applications ranging from the territorial to the architectural scale, involving historical artefacts, such as the nineteenth-century Tito Acerbo Institute in Pescara [Palestini 20I8, pp. 82I-828], urban architectures such as the survey of post-World War II educational buildings [Palestini 2019a, pp. 937-944], infrastructural structures and of the environmental context as in the case study of river basins [Palestini 20 I9b, pp.543550] (figs. 2, 3).

The experiences as a whole served to develop technical solutions relating to the choice of formats, software and the calculation algorithms most suited to obtaining the best
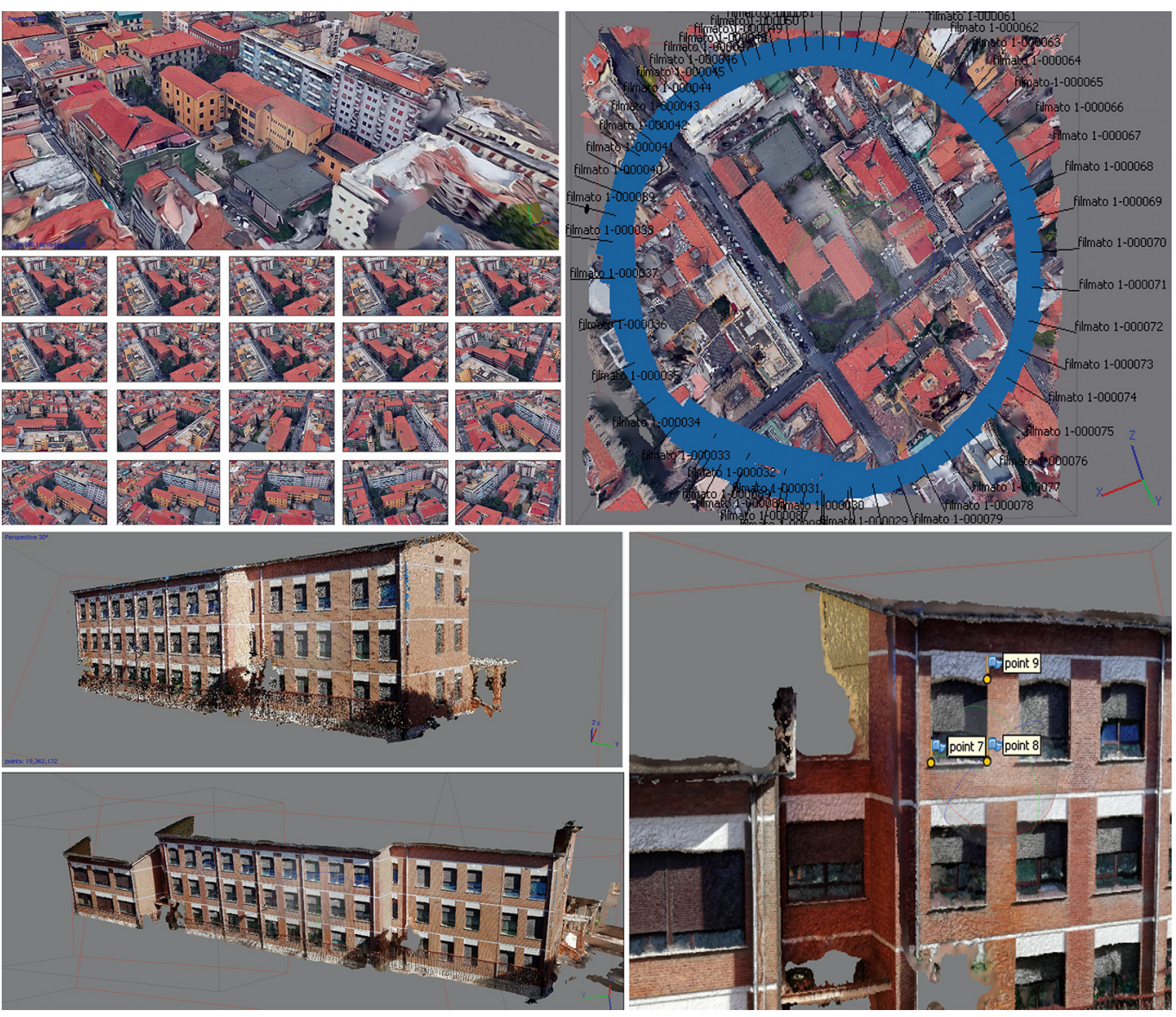


\section{Camera Locations}
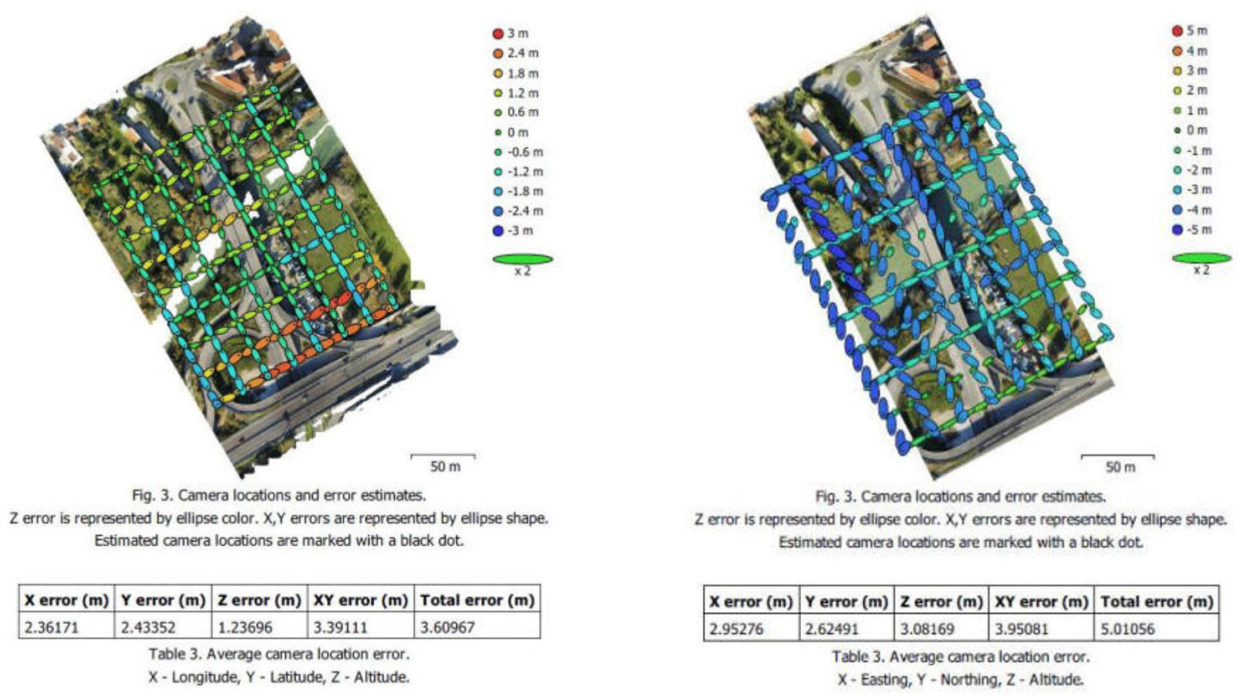

\section{Ground Control Points}

Fig. 4. Camera Location and Ground Control Point report, surveys portion of AternoPescara river basin (2019).

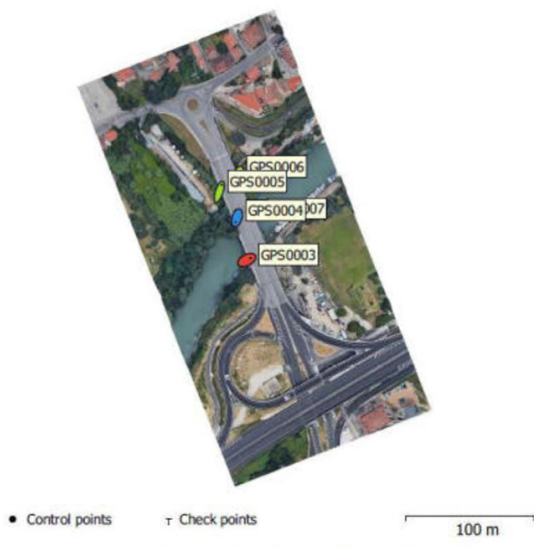

Fig. 3. GCP locations and error estimates. $Z$ error is represented by ellipse color. X,Y errors are represented by ellipse shape. Estimated GCP locations are marked with a dot or crossing.

\begin{tabular}{|l|l|l|l|l|l}
\hline Count & X error $(\mathrm{cm})$ & Y error $(\mathrm{cm})$ & Z error $(\mathrm{cm})$ & XY error $(\mathrm{cm})$ & Total $(\mathrm{cm})$
\end{tabular}

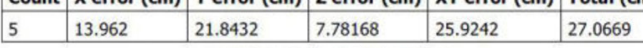
Table 3. Control points RMSE.

$X$ - Easting, $Y$ - Northing, Z - Altitude.
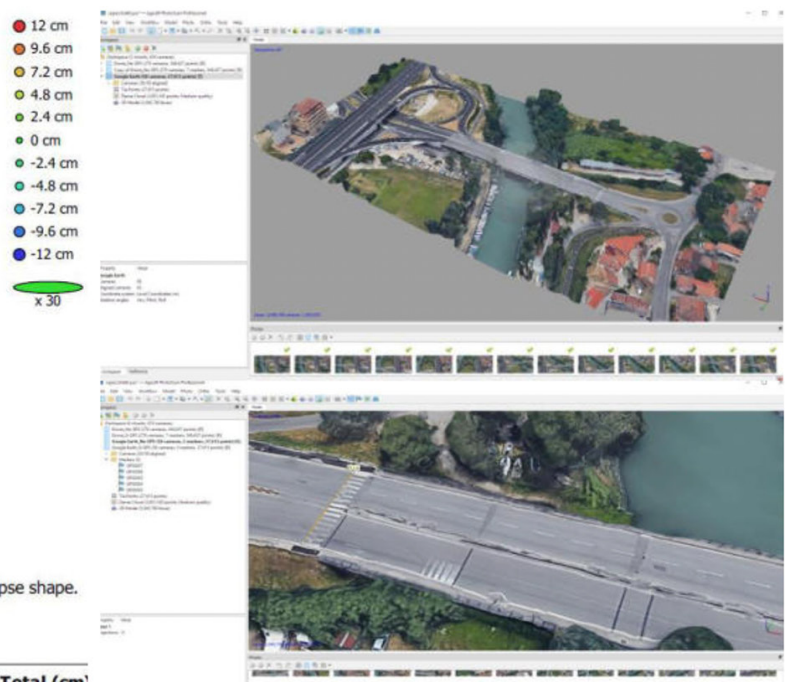

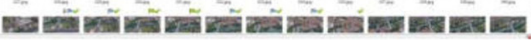

results, outlining the structure of the fast and stable executive workflow, suitable for obtaining a metric-proportional model as accurate as possible to the real sample. All the case studies examined share a similar operative methodology: the use of terrestrial and aerial photogrammetry, assisted by Unmanned-Aerial-Vehicle (UAV) systems, in addition to the experimental photogrammetric survey carried out by virtual drone. The results obtained in the various experiments were compared in order to check the error, level of accuracy and comparability of the resulting results, which were useful in defining the achievement of the required goals. In the digital reconstruction of various case studies, including a series of schools located in central and peripheral areas of the city, the methodologies described proved useful considering the results obtained, the speed of acquisition and processing, and the accuracy. The flight plan was structured using a smartphone app, and the flight and aerial image acquisition phase was almost completely automatic, providing data with a permissible centimetre error considered on the flight altitude and the resolution of the optics. 
Fig. 5. Integrated surveys, comparison between re and virtual drone data acquisition. Borgo Marino school institute (2019)
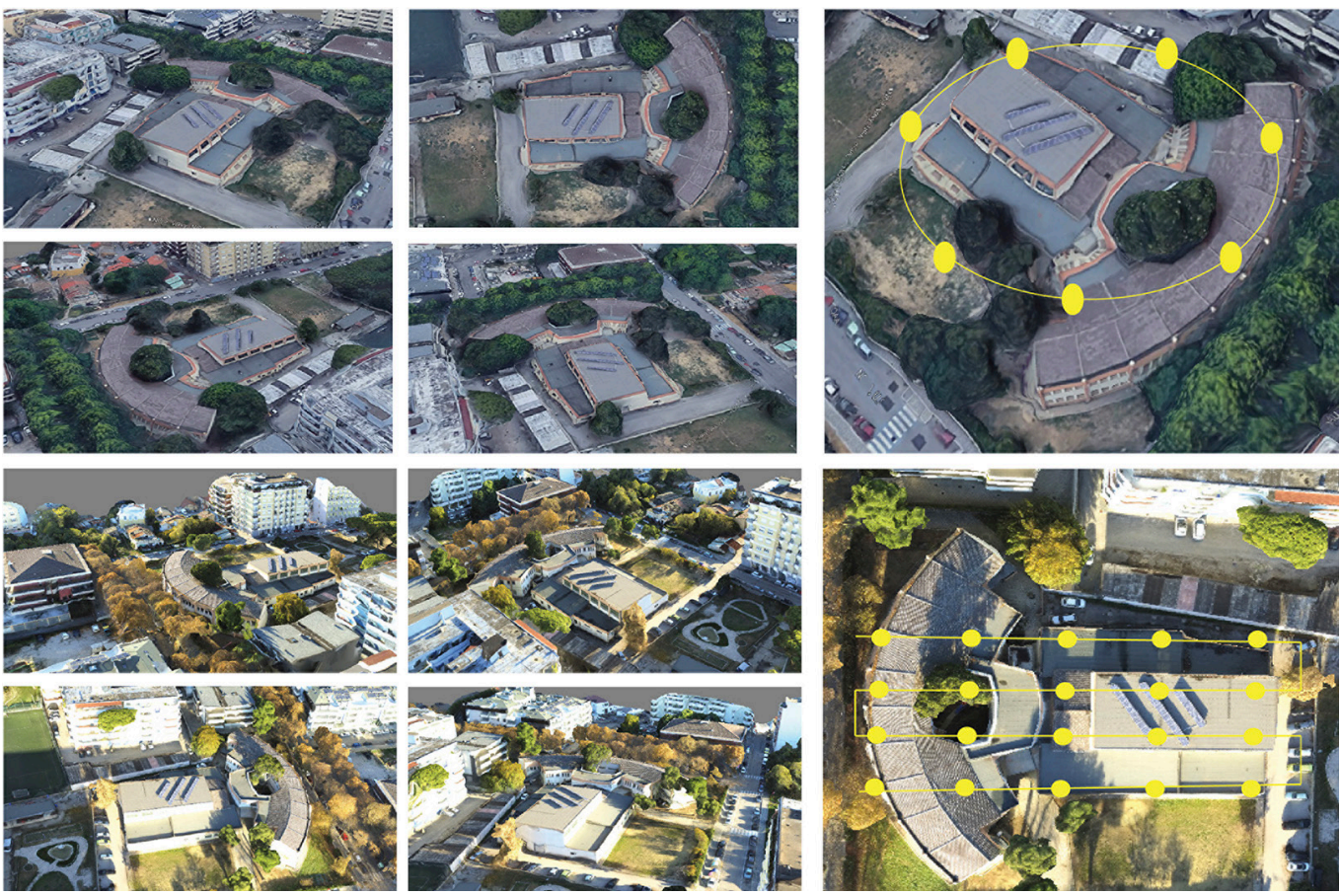

Fig. 6. Phases of data acquisition and processing (left) Dom uis bridge in Porto and (right) Trinity bridge in Mancher 2020).
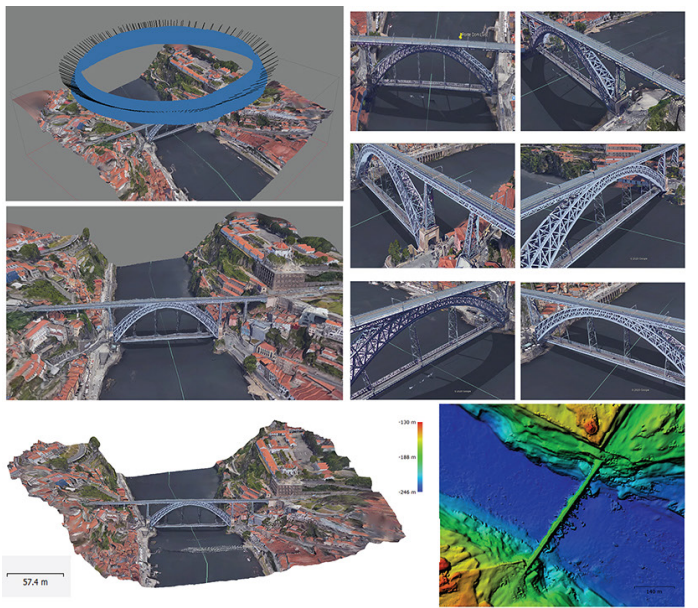
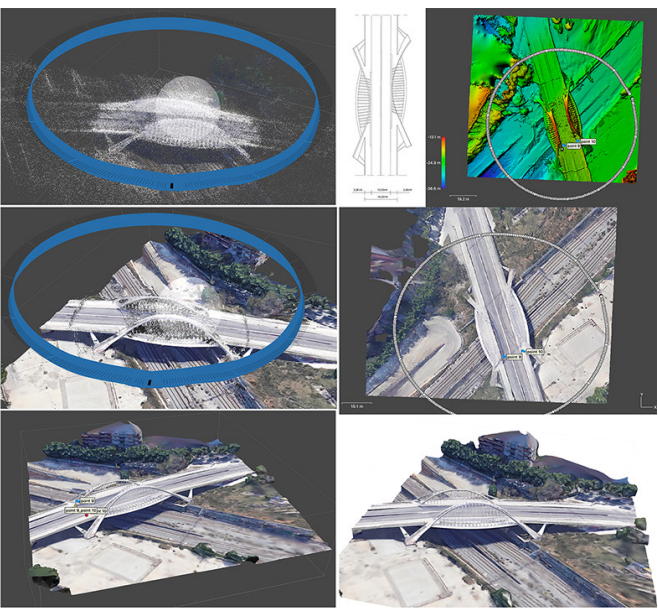

The aerial images from the drone were then integrated with the screen-shots acquired during the virtual tour planned on the Google Earth Pro platform, allowing in parallel an extrapolation of the three-dimensional plastic data of the urban portions examined. The aerial images from the drone and those deriving from Google Earth provided the desired comparisons, allowing verification of the same portions acquired with the two operating systems. The operations of analysis and data acquisition applied to larger portions of the territory, such as the river portions, made it possible to focus attention on the criticalities of a complex environment with heterogeneous connotations that vary from predominantly naturalistic areas to strongly anthropised areas. The surveys carried out along the Pescara-Aterno river offered the possibility of making direct comparisons, accompanied by numerical data, between the cloud of points generated by the images acquired by the real drone and those created through the trick of the virtual drone. Specifically, the first difference that comes out of the models is the scale measurement. The real drone allows photographs to be taken with position information and technical specifications of the optics, allowing the software to create a model already to 

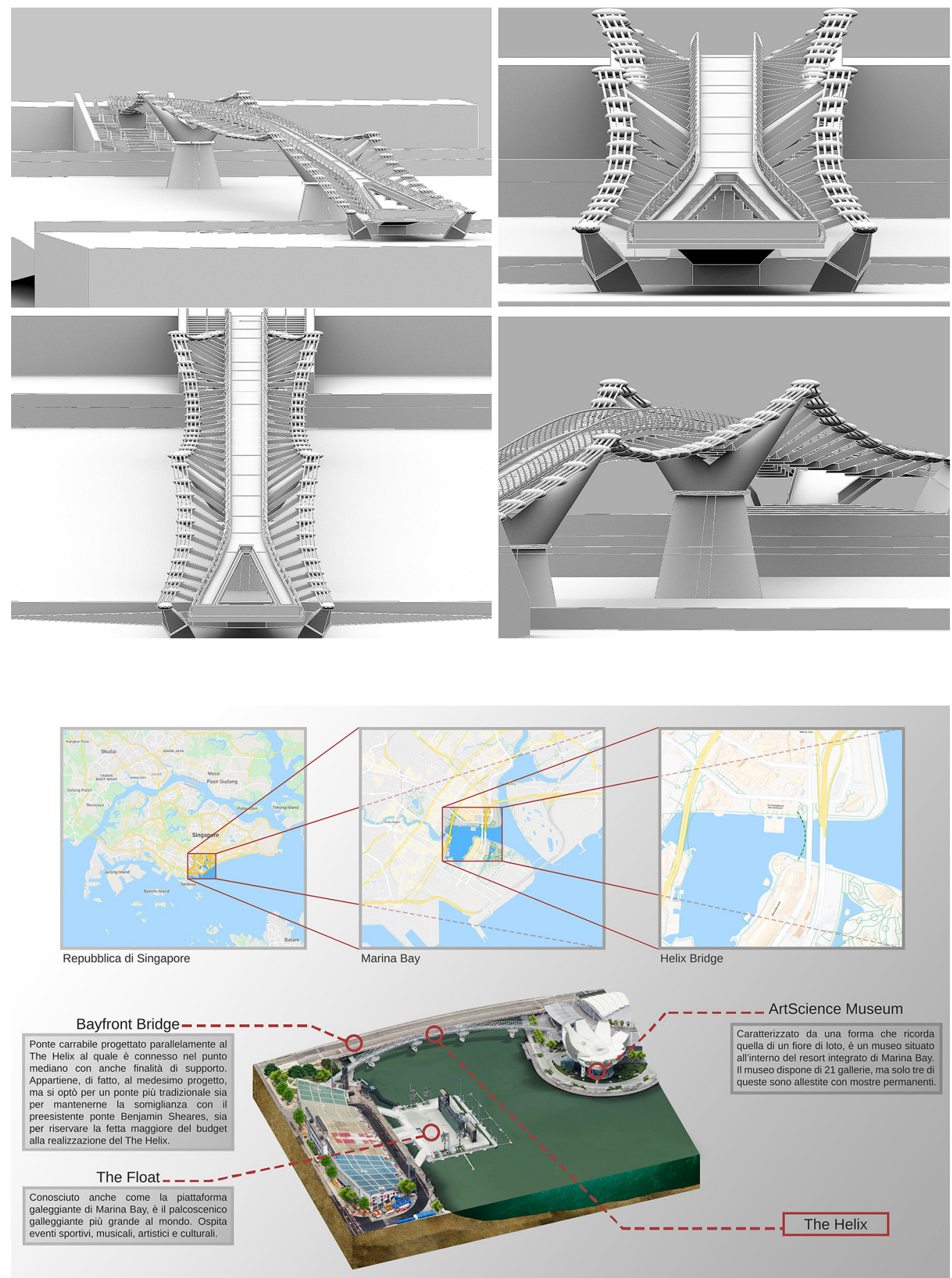

scale. This is not the case with the data from the point clouds returned by Google because they are made up of images without metadata. The software then generates an initial proportionate model but to which control measurements must be associated to scale the model. The error is obviously linked to the resolution of the images; the less detail, the greater the error deviation. In order to assess the level of error, support points, acquired with precision GPS, were taken within the created clouds, thus generating markers as absolute points on which to constrain the model. Basically, by detecting and positioning at least 4 real points and materialising them inside the generated cloud, we induce the programme to make the same virtual points coincide with those taken physically. This operation will generate an error, due to 

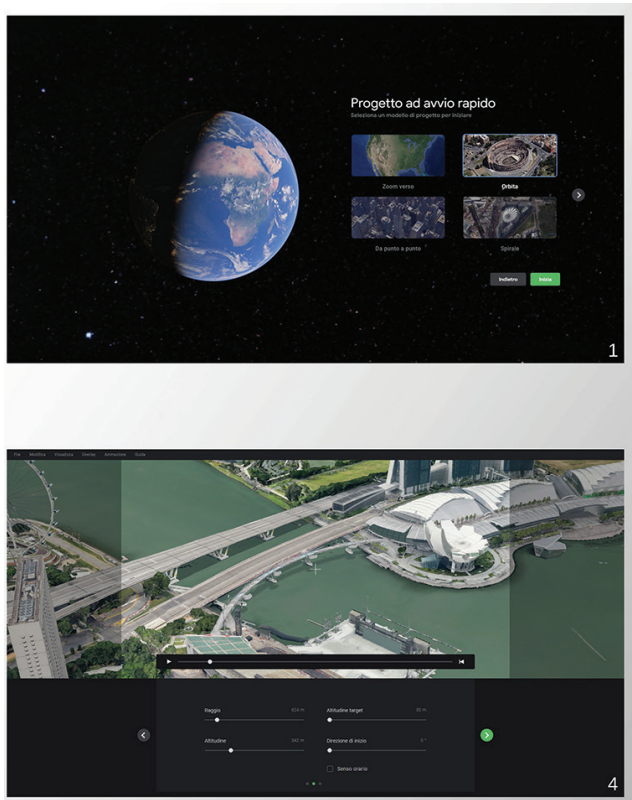

È possibile effettuare delle riprese aeree "virtuali" sfruttando le carte geografiche e i modelli tridimensionali di Google. Per la creazione del piano di volo possiamo sfruttare il sofisticato tool, sempre di proprietà di Google, Earth Studio.

1. Accedere al sito https://earth.google.com/studio/.

2. Scegliere, tra quelle offerte, la tipologia di piano di volo che meglio soddisfi le nostre esigenze (in questo caso l'orbita).
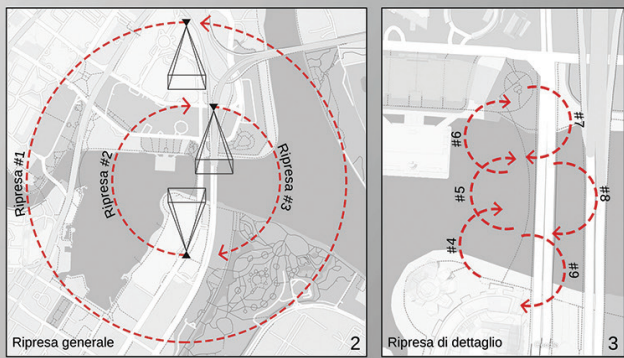

3. Definire il centro dell'orbita.

4. Impostare i parametri relativi alla quota, l'inclinazione della visuale, il raggio di copertura e, infine, la durata del tempo di volo, espressa in secondi.

5. Impostare i parametri relativi al numero dei fotogrammi da acquisire e la relativa dimensione.

6. Procedere con l'acquisizione delle immagini.
Figs. 9, 10. Phases of data acquisition and processing of The Helix bridge, Singapore Marina Bay (DAD March 2020)

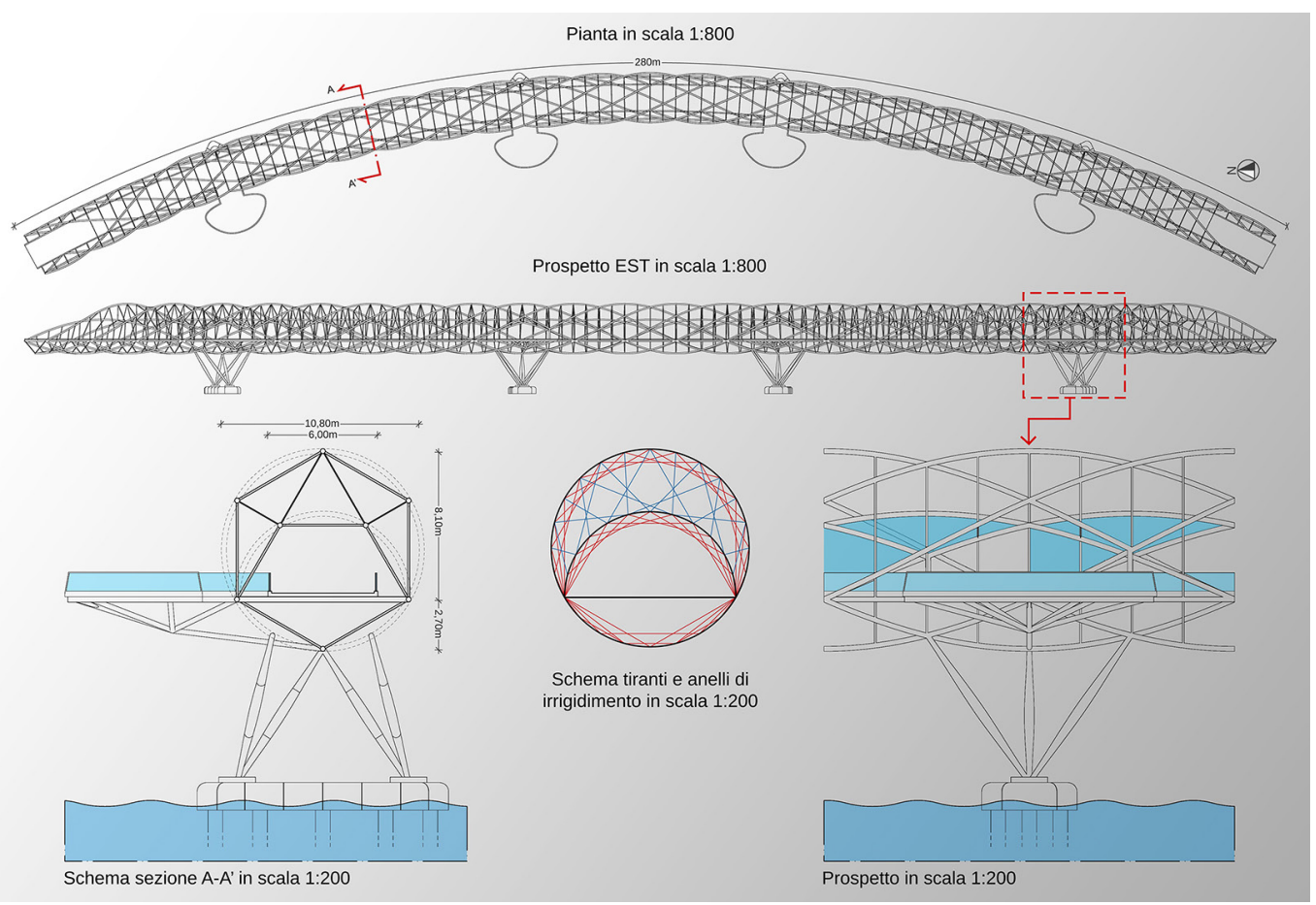

the corrective adaptation that the software will apply to the model in order to fill it with the established markers. The results of the comparison show that the model generated from images taken from Google Earth obviously suffers from limitations such as loss of resolution, lack of georeferencing and no focal exif data (fig. 4). Nevertheless, the software processes the point cloud from the sequence of 60 manual screenshots simulating the flight plan grid, demonstrating that it is possible to apply the scaling factor and GPS coordinates taken physically on the Google generated cloud. Once the GPS coordinates have been applied, it is possible to derive the error due to the uncertainty in the relationship between the pixel density and the manual positioning of the GPS markers applied on the photographic images to be processed. 


\section{Experiences of surveying in distance learning}

The comparisons described above lead to the applications tested in distance learning, launched as an emergency solution in the first lockdown with the Dpcm of 4 March 2020. The need not to interrupt university teaching involved a considerable organisational effort, especially for application and laboratory subjects that require graphic interaction in presence, such as the data acquisition phases typical of surveying. It seemed impossible to make the students practice the operational procedures required in the canonical measurement operations, yet despite the criticalities of the forced immersion in this system of on-line participation, carried out mainly by streaming, by implementing the aforementioned experiments in 'virtual' surveying, appreciable results were obtained, on which it is worth reflecting (fig. 5). A series of contemporary bridges, chosen on the basis of their technical characteristics and the three-dimensional coverage of the Google Earth Pro footage, were assigned as study topics in the Engineering course. In this regard, we report some works that as an example show the methodology followed by the students, including the survey of the historic bridge Dom Luis built in the late nineteenth century in Portugal. The bridge is the result of a competition to build a link between the two banks of the River Duero in the city of Porto, which has a large orographic difference in height between the urban centres to be connected. The choice was to build a two-storey arched bridge using a metal structure, which was daring compared to the time of construction, entrusted to Thèophile Seyrig, a disciple of Gustave Eiffel, who drew up the avant-garde design.

The Dom Luis bridge is an arch bridge built on two iron decks, the upper one approximately $385 \mathrm{~m}$ long at $62 \mathrm{~m}$ above the river and the lower one $172 \mathrm{~m}$ long at $10 \mathrm{~m}$ above the river, both supported by an iron arch with a span of $172 \mathrm{~m}$ with five intermediate piers anchored to the two banks by masonry piers. The example in question was interesting from the point of view of surveying because of the plasticity of the orographic situation and the restitution of the design of the metal structure of which it is composed. The operational sequences show the data acquisition and processing phases with the alignment of the images taken by virtual drone, followed by the configuration of scattered and dense clouds and the relative 3D and DEM models, from which the ortho-mosaic and the three- and two-dimensional representations are derived (fig. 6).
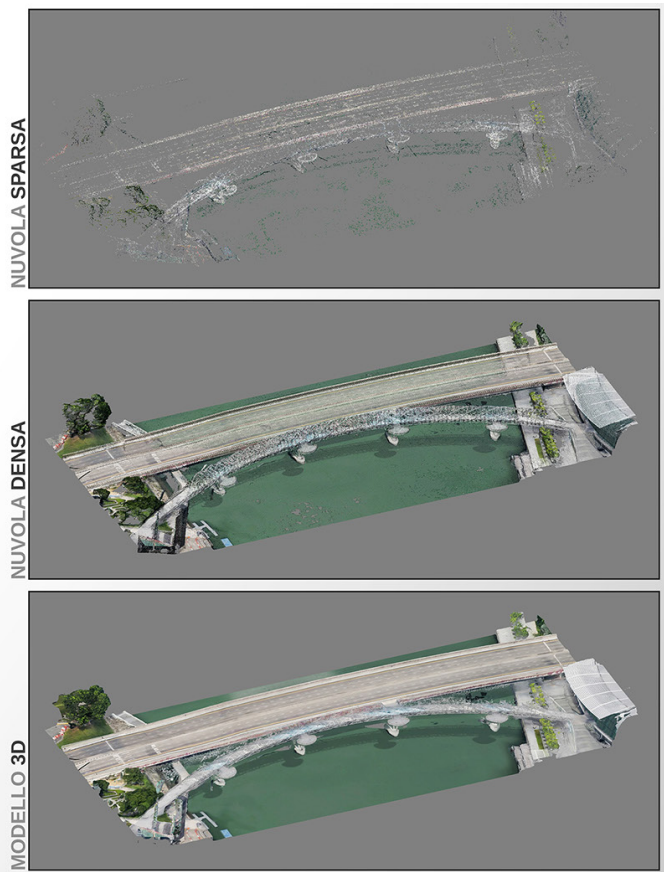
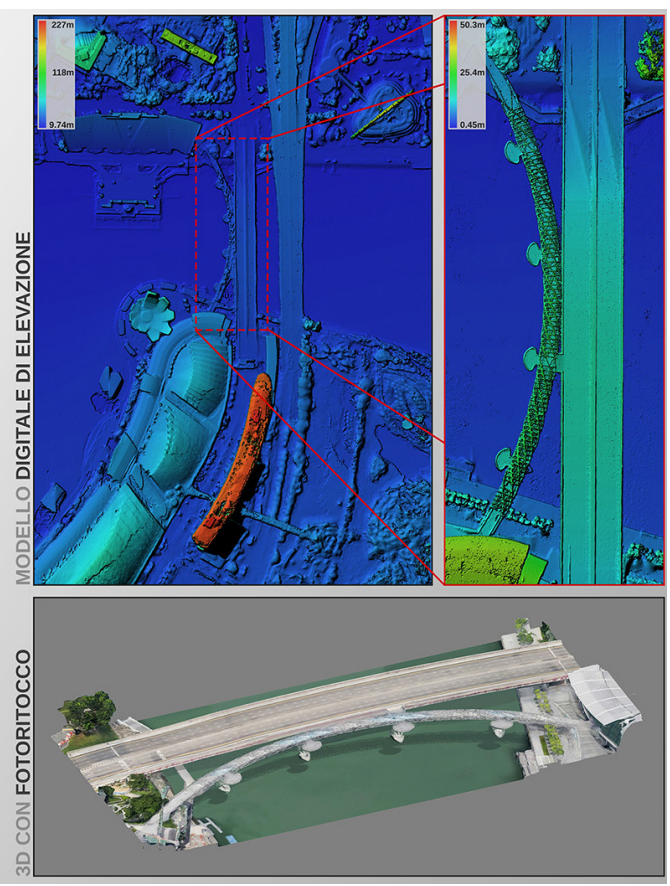
Other cases concern some of Calatrava's bridges, including Trinity Bridge in Manchester and Bac de Roda in Barcelona, which combine the formal aspect with the structural complexity of the design components. Further experimentation was conducted by integrating surveys with three-dimensional modelling, as in the case of Norman Foster's Millennium Bridge in London, which connects St. Paul's Cathedral (to the north) with the Globe Theatre and the Tate Modern Gallery, providing an innovative link between the two banks of the Thames (fig. 7). A similar process involved the survey of the complex connecting the two areas of Singapore's Marina Bay, the result of an international design won by the Cox Group and Architects $6 \mathrm{I}$ and the Arup design studio, which redeveloped the area with the construction of the pedestrian bridge known as the Double Helix Bridge: it consists of a steel double helix inspired by the structure of DNA. In the acquisition phase it was possible to choose the virtual flight plan, define the centre of the orbit, set the parameters relating to the altitude, the inclination of the view and the coverage radius, establishing the parameters relating to the number and size of the frames considered necessary to process the image-based survey phases (figs. 8-II).

As far as the Architecture course is concerned, in continuity with the experiments previously discussed, the buildings and school structures of the second half of the twentieth century have been taken into consideration on a more detailed scale.

\section{Conclusions}

Inspired by the diffusion of low-cost survey systems that have been progressively implemented over the years, due to their executive immediacy correlated to the favourable economic feedback, an alternative system was tested that could be applied for quick surveys, verifiable and implementable with integrated methodologies based on the goals to be achieved.

The need to make these methodologies operative by comparing their results in order to carry out environmental readings and 3D reconstructions through restitution that involve the experimental use of specific software to obtain depht maps of territorial models compatible with the real ones, crossing free open data obtained from the photogrammetric reconstructions of Google Earth Pro and information provided on situ by RPAS (Remoted Piloted Air System) instruments that make use of image-based methodologies for open source surveys between real and virtual (fig. I2).

Google, a veritable powerhouse in the digital industry in terms of investment, marketing and communication capabilities, has focused globally on the most innovative remote sensing techniques, spending a great deal of effort on solutions that are not expressly attributable to the Geomatic model, but which function as a sort of creative accelerator for diversified operations, from territorial surveys to architectural design, but also for the use of data for scientific or research purposes, as in the experiment described above. This adopts an alternative executive pipeline that is easy to implement and affordable for everyone, allowing photomodelling operations using previously processed 3D images. This highly low-cost procedure makes it possible to quickly obtain an initial semi-detailed study model to be used in manual remodelling operations, to create 3D spatial backgrounds to be used for renderings or to define urban settings useful for the insertion of architectural projects.

In conclusion, the contribution poses reflections on possible implementations of Google's information containers to be used specifically in remote teaching. By means of the described methodology it was possible to obtain surveys and study models suitable for the reconstruction and 3D analysis of territorial areas through image-based survey systems. The ease of use of the workflow allows easy use in distance learning, giving students the opportunity, as documented in the examples described, to experiment with data management for survey operations and architectural representations.

Integration with dedicated software can also make it possible to interact with virtual methodological applications that can be applied at different architectural and urban scales. 
Fig. 12. DAD Lecture: Remote data acquisition phases with virtual drone (October 2020).

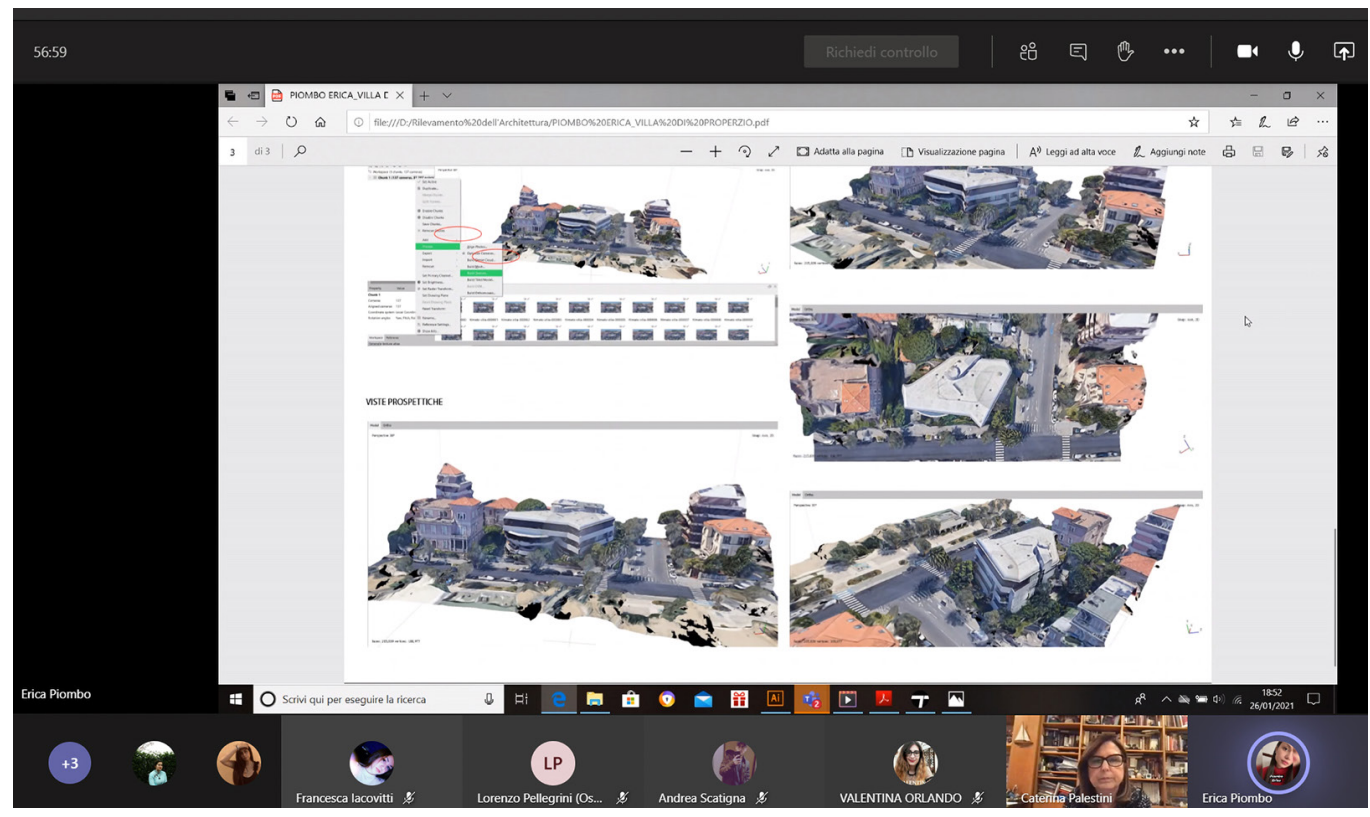

\section{References}

Bianchini C. (20I4). Survey, Modeling, Interpretation as multidisciplinary components of a knowledge system. In SCIRESIT, n. 4 (I), pp. I5-24

Cundari C. (1984). Fotogrammetria Architettonica. Bologna: Kappa.

De Luca L. (20 I I). La Fotomodellazione Architettonica. Palermo: Flaccovio Editore.

Magallanes G., et al. (20।8). Modelling of collective movement in immersive environments. In International Archives of the Photogrammetry, Remote Sensing and Spatial Information Sciences, vol. XLII-4, pp. 397-402.

Napolitano R.K., Scherer G., Glisic B. (2018).Virtual tours and informational modeling for conservation of cultural heritage sites, In Journal of Cultural Heritage, n. 29, pp. 123- 129.

Palestini C., Basso A. (2019a). Cultural Projects And Geomatic Surveys for the Resilience of School Heritage. In International Archives of the Photogrammetry, Remote Sensing and Spatial Information Sciences, vol. XLII-2MI I, pp. 937-944.

Palestini C., Basso A. (2019b). 3D Detection and reconstruction in river basins. In International Archives of the Photogrammetry, Remote Sensing and Spatial Information Sciences, vol. XLII-2N9, pp. 543-550.

Palestini C., Basso A. (2020). The UAV Survey of the Valvense Complex in Corflnlo, comparison between two photomodelling methods. In S. Barba et al. (Ed.). D-SITE Drones - Systems of Information on Cultural Heritage for a spatial and social investigation, pp. 274-283. Pavia: Pavia University Press.

Palestini C., Basso A., Graziani L. (2018). Integrated photogrammetric survey and BIM modeling for the protection of School Heritage, applications on a case study. In International Archives of the Photogrammetry, Remote Sensing and Spatial Information Sciences, vol. XLII-2, pp. 82 I-828

Santagati C., Inzerillo L., Di Paola F. (20I3). Image-based modeling techniques for architectural heritage 3d digitalization: limits and potentialities. In International Archives of the Photogrammetry, Remote Sensing and Spatial Information Sciences, vol. XL-5/ W2, 20, pp. 550-560.

\section{Authors}

Caterina Palestini, Università degli Studi “G. d'Annunzio" di Chieti e Pescara, palestini@unich.it

Alessandro Basso, Libera Università di Bolzano, alessandro.basso@unibz.it

To cite this chapter. Palestini Caterina, Basso Alessandro (2021). Rilievo a distanza: una metonimia per sperimentazioni tra didattica e ricerca/ Remote sensing: a Metonym for Experimentation between Teaching and Research. In Arena A. Arena M., Mediati D., Raffa P. (a cura di). Connettere. Un disegno per annodare e tessere Linguagoi Distanze Tecnologie. Atti del $42^{\circ}$ Convegno Internazionale dei Docenti delle Discipline della Roppresentazione/Connecting. Drawing for weoving relationship. Lang Representation Disciplines Teachers. Milano: FrancoAngeli, pp. 2513-2534. 